Madrygal. Revista de Estudios Gallegos

ISSN: 1138-9664

\title{
As pegadas do cinema na obra de Manuel Rivas
}

\author{
Salvador Castro Otero ${ }^{1}$
}

Recibido: 4 de febreiro de 2019 / Aceptado: 14 de outubro de 2019

Resumo. O cinema converteuse na forma de narración máis popular do século XX. Non pode estrañar, pois, que as súas formas de contar influísen noutras artes, en especial na literatura. Este traballo propón unha clasificación das relacións entre os textos audiovisuais e escritos e mostra os trazos característicos da sétima arte presentes nas obras literarias e xornalísticas de Manuel Rivas e, por extensión, noutros escritores da centuria pasada.

Palabras chave: Manuel Rivas; literatura comparada; relacións entre cine e literatura; estilo literario; descrición.

\section{[es] Las huellas del cine en la obra de Manuel Rivas}

Resumen. El cine se convirtió en la forma de narrar más popular del siglo XX. No ha de extrañar, pues, que sus formas de contar hayan influido en otras artes, en especial en la literatura. Este trabajo propone una clasificación de las relaciones entre los textos audiovisuales y los escritos y muestra los rasgos característicos del séptimo arte presentes en la obra literaria y periodística de Manuel Rivas y, por extensión, en otros escritores de la centuria pasada.

Palabras clave: Manuel Rivas; literatura comparada; relaciones entre cine y literatura; estilo literario; descripción.

\section{[en] The Traces of Cinema in the Work of Manuel Rivas}

Abstract. Cinema became the most popular form of narration of twentieth century. It not wonders, then, that this way of telling influenced other arts, especially literature. This work proposes a classification of the relationships between audiovisual texts and writings and it shows the characteristic features of the seventh art present in the literary and journalistic work of Manuel Rivas and, by extension, in other writers of the past century.

Keywords: Manuel Rivas; Comparative Literature; Cinema and Literature Relationships; Literature Style; Description.

Sumario. 1. Introdución. 2. A presenza do cine na literatura. 2.1. As características estruturais. 2.2. As características visuais. 2.3. As características auditivas. 2.4. As relacións intertextuais. 3. Conclusións. 4. Referencias bibliográficas.

Como citar: Castro Otero, S. (2019): “As pegadas do cinema na obra de Manuel Rivas”, en Madrygal. Revista de Estudios Gallegos 22, pp. 93-122.

1 IES de Rodeira.

Correo-e: salvaclase64@hotmail.com 


\section{Introdución ${ }^{2}$}

Cando o cinema non existía nin como sospeita, cando os seres humanos negociaban coa luz e a penumbra nas vidreiras das catedrais e nas sombras chinesas; cando os primeiros ollos atentos quixeron atrapar en pinturas e gravados rupestres o movemento; e comezaron a descompoñer e debuxar os instantes para logo botalos a rodar nos zoótropos ou nos praxinoscopios, xa, naquel tempo, o inexistente cine, contaba historias. De aí que non resulte sorprendente que a sétima arte acabe por se converter, no esencial, nunha forma de satisfacer a fame de contar, a sede de escoitar, a luxuria de vivir máis mundos que o propio, porque como expresaba Manuel Rivas (Martín de Blas 1999)3: "muchas cosas han cambiado para el ser humano pero una necesidad se mantiene, la de inventar historias para alimentar el fuego y prolongar las mil y una noches".

Sen entrar a discutir agora a quen se lle debe atribuír o invento do cinema, parece evidente que, dende as primeiras manifestacións públicas desta arte, cando os espectadores parecían máis fascinados polo aparello que polo que contaba, o cine xa estaba a transmitir historias, relataba acontecementos, recollía instantes da vida cotiá: a saída da fábrica, o xantar dun neno, a chegada do tren... Este relato dos feitos, en ocasións, mesturaba imaxes rexistradas dos acontecementos con secuencias recreadas:

Los hermanos Lumière no tuvieron problemas en filmar escenas "documentales" de guerra, supuestamente tomadas en China, a las afueras de París. Tampoco Porter, al filmar noticias de capturas de delincuentes o ejecuciones de criminales famosos, se preocupó de subrayar que el bandolero capturado a tiros en un bosque del Midwest era, en realidad, un actor, porque el verdadero bandolero estaba en la cárcel. (Taléns 2002: 5-6)

No medio deses fragmentos de vida, máis ou menos trucados, empezaba a asomar a ficción. $O$ regador regado non mostra un feito real, senón un verosímil, unha brincadeira. Mais será Mèliès quen leve a balbuciente arte polo camiño das historias inventadas e tamén polo sendeiro misterioso dos efectos visuais. Se Le voyage dans la lune (1902) sorprende polo imaxinativo, Un homme de têtes (1898) impresiona polos xogos de sombras e as duplicacións das imaxes. O cinema convértese pois, dende o comezo, nunha forma de arte narrativa ${ }^{4}$. Ata tal punto que, como apunta Jenaro Taléns (2002: 7): "la historia del cine en tanto disciplina elige como eje principal el desarrollo técnico-sintáctico del cine narrativo, convertido sin más, no en una de las formas dominantes del cine, sino en cine a secas".

A simple vista podería parecer sinxelo distinguir cine de literatura. Cine sería segundo a definición de Jean Renoir: "Todo lo que se mueve en una pantalla" (apud Trueba 2006: 86). Abondaría, pois, con referirse ao soporte, a gravación audiovisual (en celuloide, vídeo, DVD...) fronte ao libro. Sucede, non entanto, que esta división pode resultar insuficiente para explicar toda a complexidade das creacións audiovisuais.

En Tutto Dante (2006) Roberto Benigni comenta A Divina Comedia e analiza as características poéticas, simbólicas e históricas da obra; é dicir, imparte unha clase de literatura que remata coa recitación dos cantos comentados previamente. Este espectáculo pode, polo feito de estar filmado, considerarse cine? Probablemente non. Constitúe, sen dúbida, un documento, daquela un documental, pero os versos de Dante seguen a ser literatura e a clase maxistral, no dobre sentido, de Benigni, unha acción didáctica.

José Pedro Camello Manzano en El domador de palabras (2000) recrea versos de César Vallejo, Blas de Otero, Luis Cernuda, Federico García Lorca, Miguel Hernández e Mario Benedetti. $O$ realizador acompaña o recitado dos poemas cunha banda sonora e con imaxes evocativas, pero non miméticas, de grande beleza. Non estamos pois, como no caso de Benigni, diante de planos do recitador (con algunha inserción do público e dos monumentos da praza), senón de imaxes e música que acompañan, ao tempo que enchen, se cabe, de intensidade

Este traballo ten a súa orixe nun capítulo da tese de doutoramento titulada Manuel Rivas e o cine, dirixida pola profesora Carmen Becerra Suárez e defendida na Universidade de Vigo.

Juan M. Martín de Blas dirixiu o documental Galicia, arpa de niebla do que Rivas foi coguionista e narrador.

4 Existen outras expresións cinematográficas non narrativas. Pere Guimferrer (1999: 47-48) e Teresa García Abad (2005: 20-21), por exemplo, sinalan a existencia dun cine poético baseado máis no plano que na secuencia e, polo tanto, máis achegado á poesía. 
os versos evocados. A beleza das imaxes e a elegante e variada montaxe converte en cine o texto literario, ou talvez as fronteiras entre ambas artes dilúense, esváense, xúntanse nunha aperta na que resulta imposible, por impreciso, establecer os lindes?

Consideremos finalmente o comezo de Manhattan (1979), a película de Woody Allen. O director preséntanos mediante a voz en off (como os recitados da obra anterior) un escritor lendo os distintos comezos dunha obra literaria sobre Nova Iorque que está a redactar. As diversas versións van acompasadas polas imaxes (neste caso si, bastante miméticas) e a música de George Gershwin. Este arranque é un produto literario ou fílmico? Allen xoga a balancearse entre eses dous mundos, non só porque o inicio da película se corresponde co comezo dunha imaxinaria novela, construída ao ritmo das palabras, senón porque as imaxes beben das verbas e non as verbas das imaxes. Se cadra, como sostén Teresa García-Abad:

La literatura y el cine se funden así en una idéntica y común pretensión de contar historias, tal vez el cordón umbilical más indiscutible entre las dos disciplinas en ese inacabable tejer y destejer similitudes y discrepancias, hasta tal extremo que Morris Beja propone hablar de un único arte, el de la literatura narrativa, del que las novelas y las historias filmadas serían una parte. (2005: 94)

Luis Goytisolo apuntaba no seu discurso de ingreso na RAE, que a literatura se viu afectada polos avances tecnolóxicos ${ }^{5}$ :

Me voy a centrar ahora en algunas de las buenas nuevas que traía consigo el fin de siglo pasado, que son en definitiva las que han condicionado el nuestro. Y digo algunas -la fotografía, el cinematógrafo- porque pese a ser muchos más los inventos que, al incidir en todos los órdenes de la vida, han incidido también en la narrativa el telégrafo, el teléfono, la radio, el automóvil, el aeroplano, las estructuras metálicas-, el impacto de la fotografía y el cine, como posteriormente de la televisión, sobre la narrativa -que es el tema elegido en mi discurso- ha sido mucho más directo. (1995: 15-16)
Grazas a estes novos instrumentos o lector actual coñece a través das imaxes fotográficas e televisivas o aspecto de moitos lugares afastados, polo que o escritor, tal como expresa o académico no seu discurso (1995: 18-19), non está obrigado a describilos. Por outra banda, a televisión, instalada na intimidade do fogar, transfórmanos, en maior ou menor medida, en telespectadores:

La aparición de la televisión y, sobre todo, la generalización del fenómeno televisivo suponen un nuevo y más decisivo factor condicionante en el desarrollo de la narrativa, no ya desde el punto de vista formal y técnico sino también sociológico. Afecta de un modo directo a la lectura-justamente por lo que tiene de cotidiano y doméstico-e indirectamente a la propia escritura, en la medida en que todo nuevo escritor ha sido y es, además de lector, telespectador más o menos asiduo. El fenómeno televisivo -expresión con la que designo la estrecha dependencia creada entre la programación televisiva y el público-no supone en efecto una mera elección alternativa, como la que puede existir entre leer e ir al cine. Más que opción es invasión: invade pura y simplemente, a domicilio, la vida cotidiana, $\mathrm{y}$ antes que interpretar la realidad circundante, la sustituye, se constituye en realidad y entra a formar parte del reparto horario del día -un tiempo como el destinado a comer o dormiren la vida de un número cada vez mayor de individuos. El fondo del problema no reside como tanto se nos repite- en que, a causa de tal invasión, se vaya menos al cine o se lea menos; el verdadero núcleo del problema estriba en que el fenómeno televisivo tiende a excluir a la vez una y otra actividad en beneficio de una nueva forma de privacidad que, de un modo natural, tiende a establecerse directamente entre televisor y telespectador. (Goytisolo 1995: 22-23)

O cine vai conformar, ao longo da súa evolución, unha linguaxe propia. Unha linguaxe da que tamén se beneficia a literatura.

Esta sucesión de fotos animadas articulada en secuencias que es el cine supone algo más que una mera alteración en la forma de percibir la realidad circundante: supone la irrupción de una nueva forma de narrar formulada, no verbal, sino visualmente. Se podrá objetar que

5 Carlos Aurelio López Piñeiro (2018: 52 e ss.) divide a historia do cinema en catro grandes etapas e as relaciona coa aparición dun aparello, así o cinema primitivo e preclásico (1895-1931) é o resultado da experimentación no campo da fotografía; o cinema clásico (1931-1955), que xurde paralelo ao son, coincide coa presenza masiva da radio nos domicilios; o cinema moderno (1956-1980), co seu manierismo, é unha resposta á instalación nos fogares da televisión e o cinema posmoderno (1981-2005) á irrupción do vídeo doméstico. 
pensamos con palabras, no con imágenes, y que, en consecuencia, un planteamiento escrito -un guión- precede siempre al cine, incluso al cine mudo. Yo creo que así es, en efecto, pero eso no impide que la expresión del relato sea inminentemente visual. Y el hecho es que hoy día son muchos los escritores que aseguran pensar sus obras a partir, no de palabras, sino de imágenes; yo no lo creo posible, pero si ellos están convencidos de lo contrario, allá se las compongan con sus obras, que inevitablemente acusarán el efecto de semejante hábito o propensión. No deja de ser sintomático que un escritor crea pensar no en términos de ideas -en definitiva, palabras- sino de imágenes. (Ibid. 19)

Fronte a esta nova forma de narrar, os autores poden afastarse o máis posible para buscar unha identidade, ou asumir formas da nova arte para así ampliar os seus rexistros:

Centrándonos ya en nuestro asunto, yo diría que la narrativa española contemporánea [...] ha reaccionado ante el relato cinematográfico fundamentalmente de dos maneras. La primera de ellas consistiría en un movimiento de aproximación al nuevo género tendente a asimilar sus recursos del modo más completo posible a fin de poder competir con él ofreciendo al lector un producto análogo, por más que expresado en palabras. [...]

De ahí que, frente a esa tendencia, desarrollada de forma paralela y simultánea, se nos ofrezca la tendencia opuesta, que busca, antes que aproximarse a la imagen, apartarse de ella, crearse un propio ámbito irreductible. (Ibid. 25-26)

$\mathrm{Na}$ actualidade empregamos o termo nativo dixital ou homo sapiens digitalis para designar os seres humanos nacidos cando xa existía unha tecnoloxía informática desenvolvida e espallada. Resulta imposible explicar o mundo e o comportamento dos nosos mozos sen ter en conta as videoconsolas, os videoxogos, os teléfonos móbiles e outras innovacións. Cando as últimas xeracións contan as súas historias, a presenza destes instrumentos non precisa ser explicada e o léxico propio destes aparellos flúe con naturalidade. Se retrocedemos na historia e lemos El conde Lucanor, Os contos de Canterbury, As mil e unha noites, ou, máis modernamente, os textos de Ánxel Fole, por exemplo, observamos a pervivencia, os ecos fecundos, dos contos tradicionais; os seus autores interiorizáronos como quen aprende a comer e por máis que os máis modernos coñezan tamén a Homero, Cervantes, ou a Víctor $\mathrm{Hu}-$ go, poñamos por caso, resulta innegable que aquelas narracións a carón do lume deixaron pegadas moi recoñecibles na súa forma de escribir.

Alberti (1994: 73) expresaba con orgullo: "Yo nací - respetadme- con el cine". Os coetáneos do autor de Marinero en tierra conviviron co inicio da sétima arte, co gatear, cos primeiros pasos, coas primeiras verbas deste invento. Pero ese neno acabou por conformar unha forma propia de expresarse, unha linguaxe. Para os primitivos espectadores case todo constituía unha sorpresa: a aparición dun tren proxectado nunha parede, a técnica de montaxe... Mais as promocións posteriores xa mamaron, xa se alimentaron con ela e medraron contemplándoa. Esta xeración, nacida cando o cinema era unha tecnoloxía desenvolvida e espallada -o espectáculo por excelencia-, ben merecería ser chamada homo sapiens filmicus ou simplemente homo filmicus. Este homo filmicus, habituado a recibir as historias no silencio e na escuridade da sala de cine, empregará, de modo natural, tanto nas conversas informais como nos textos máis elaborados, as formas de contar da sétima arte. Convén pois preguntarse cales son as pegadas do cinema nas formas de construír os relatos na literatura, como a recepción das historias a través das imaxes transforma a forma de contar as fábulas dos homes de letras.

Para Goytisolo os principais trazos propios do cine na literatura serían:

[la] visualidad de las descripciones, [el] carácter enunciativo y coloquial de los diálogos y la estructura narrativa articulada en secuencias. También la concepción misma del conjunto, el predominio del relato en tercera persona -aunque el uso de la primera puede dar lugar a un juego virtuoso que tampoco ha dejado de tentar al propio cine- y la especial importancia del punto de vista narrativo. (1995: 24)

Apunta ademais que:

Este énfasis en la visualidad de las descripciones, perceptible ya aquí y allá en diversas obras de la primera mitad del presente siglo, se generaliza en la segunda mitad -incluso en obras difícilmente filmables-y termina por convertir en poco más que guiones cinematográficos o televisivos -por lo general escasamente afortunados- una buena parte de la producción novelística de los últimos años. (Ibid. 24)

Patricia Antón (2007) parte do exposto no discurso de Goytisolo, mais sinala algúns novos trazos. Segundo esta autora o aspecto visual das descricións, xa comentado, adquire un carácter 
máis cinematográfico a través da ocularización, é dicir, da narración ou descrición a través dos ollos dun personaxe. Detecta ademais que igual que no cine na literatura atopamos coa presenza dunha imaxe dentro doutra imaxe; así, o espe1lo, "El único [elemento] que consigue convertir al personaje que observa a los demás en observador de sí mismo" (2007: 249), e os retratos, que nos permiten podemos comparar uns personaxes con outros e incluso un mesmo personaxe en distintas etapas da súa vida, transitan pola ficción literaria coa mesma naturalidade que nos fotogramas. Esta investigadora destaca ademais o uso da música e dos ruídos como banda sonora:

La música posee también un valor fundamental en la trilogía -Carlos y doña Mariana charlan entretenidamente mientras escuchan viejos discos o éste la deleita tocando alguna pieza de piano; la interpretación que Germaine hace del Ave María con motivo de la inauguración de la iglesia, supone un momento cumbre en la trilogía... - unida a todo tipo de sonidos ambientales- conversaciones de fondo, el estruendo de las máquinas del astillero... como si de una banda sonora cinematográfica se tratara. (Ibid. 256)

Outro trazo moi destacado, para a nosa investigadora, é a utilización simbólica da luz: "Este elemento visual remite a un código inexistente en la narración verbal, típicamente cinematográfico, logrará desempeñar una función caracterizadora importantísima de alguna escena" (Ibid. 256). Por outra banda, as mencións ao cine serven para caracterizar aos personaxes novelescos ao identificalos con outros cinematográficos e para permitir os personaxes transcender "la dura y asfixiante realidad de los personajes" (Ibid. 260). Aínda que non o menciona dentro dun apartado específico, aquí e alí, mostra como algunhas descricións de Torrente Ballester en Los gozos y las sombras -obxecto do seu estudo- imitan os planos ou determinados movementos de cámara:

Aunque en este caso, parece detectarse un movimiento de los ojos de Carlos, actuando a modo de cámara, de abajo arriba, lo más llamativo resulta el acercamiento gradual del objetivo, como si de un zoom se tratase, desde un plano medio (no olvidemos que está sentada) hasta un primerísimo plano de las uñas, pasando por el primer plano del escote y de las manos. (Ibid. 242)

La enumeración de los distintos enseres del cuarto siguiendo un orden sucesivo intenta reproducir el travelling de una cámara cuyo objetivo se correspondería con los ojos del protagonista. (Ibid. 241)

Son moitos os traballos que sinalan as relacións entre estas dúas artes mais parece preciso ofrecer unha visión completa e ordenada da presenza das formas de narrar do cine nas formas literarias de contar.

Resulta imposible analizar a obra de todos os escritores pertencentes a esta xeracións, por iso, aínda sendo conscientes do parcial que sempre resulta limitar o campo de estudo a un só autor, fundamentaremos a nosa proposta a partir dos exemplos extraídos da obra de Manuel Rivas, un narrador profundamente cinematográfico:

Los textos de Manuel Rivas toman cuerpo y se deslizan de la palabra a la luz a través de una mitología fílmica que actúa como sustrato en el proceso de creación del autor gallego desde su contacto emocional con el cine en los escenarios de la niñez. (García-Abad 2005: 102)

Manuel Rivas (1957) ocupa un lugar central dentro do panorama das letras galegas actuais: trátase do escritor en lingua galega máis traducido da historia ${ }^{6}$; universidades prestixiosas organizan xornadas sobre a súa obra ${ }^{7}$; e outros autores de renome recoñecen a súa capacidade como escritor ${ }^{8}$. Foi galardoado co Premio Torrente Ballester, co Premio Nacional de Narrativa, e con tres Premios da Crítica española e dous da Crítica galega, entre outros.

O caudal de cine na obra de Manuel Rivas supera as marxes do que podería ser unha simple reflexión sobre a sétima arte, para anegar

6 Está versionado en máis de vinte linguas algunhas moi estendidas como o inglés ou o francés e outras minoritarias como o tetún ou o danés. Por outra banda a súa obra $O$ lapis do carpinteiro é a novela galega máis traducida da historia da nosa literatura.

7 O Centre de Recherches Interdistiplinaires sur les Mondes Ibériques Contemporains organizou en 2010 unhas xornadas sobre Manuel Rivas e Suso de Toro tituladas: Manuel Rivas et Suso de Toro: deux voix de la littérature galicienne contemporaine.

8 Günter Grass: "He aprendido más de la guerra civil española leyendo El lápiz del carpintero de Manuel Rivas, que en todos los libros de historia" (www.alfaguara.com/es/libro/las-voces-bajas/) [última consulta 19/12/2018]. 
toda a súa creación, como demostra a aparición de referencias a máis de 150 películas, máis de 75 directores, máis de 50 actores e máis de 50 personaxes. Aparecen ademais mencións a oficios menos coñecidos como directores de fotografía, maquilladoras, extras, meritorios, acomodadores, pertiguistas, etc. Alude as salas de cine, as técnicas, os xéneros e mesmo os aparellos do cinema.

Convén non esquecer que Rivas redactou os argumentos de A rosa de pedra e da serie de televisión Vivir sin permiso, os guións de documentais (Galicia, arpa de niebla e E punto final) e da longametraxe Todo es silencio, polo que foi seleccionado para os Premios Goya, participou como actor -un cameo en $O$ lapis do carpinteiro-, e dirixiu a curtametraxe Mayday mayday.

Todos estes factores convérteno nun autor ideal para estudar as relacións entre cinema e literatura.

\section{A presenza do cine na literatura}

Somos conscientes da dificultade de establecer unha relación directa entre cada recurso cinematográfico e os usos literarios e tamén de que a orixe de moitos trazos que hoxe consideramos propios do cinema se atopan na literatura. Non obstante, atrevémonos a propor unha clasificación dos elementos máis significativos da sétima arte que podemos detectar nas letras. Na nosa opinión estes son de catro tipos: estruturais, visuais, auditivos e intertextuais.

\subsection{As características estruturais}

As características estruturais son aquelas que afectan a distribución externa e interna do discurso, é dicir, que determinan "a rede de relacións que se dan entre os elementos dun sistema" (VV.AA. 1998: 278).

Fronte a división tradicional en capítulos ou convivindo con ela, na novela contemporánea atopámonos, como xa apuntara Goytisolo, coa secuenciación. Se entendemos a secuencia cinematográfica como un conxunto de planos ininterrompidos que forman un todo coherente dentro da película, na novela, ao non existir o corte visual, o cambio dunha escena a outra implicaría un salto temporal, de escenario, de acción ou a aparición dun novo personaxe?

$\mathrm{Na}$ obra de Rivas este tipo de organización do discurso é moi frecuente. Os comedores de patacas, por exemplo, está dividido en tres capítulos, dentro dos cales existen numerosísimas secuencias. Sucede que, en contra do que adoita ser tradicional, cada unha delas leva un título ${ }^{10}$ polo que poderían interpretarse como micro capítulos. Con todo, a brevidade dos apartados e, sobre todo, os cambios radicais entre os mesmos remiten directamente as secuencias, como podemos observar no seguinte exemplo:

\section{As flores dos mortos}

Nun curruncho da eira, preto do campo de coles, a avoa ten un xardinciño con sebe de hortensias, no que coida dalias, calas e crisantemos, flores para os seus mortos. Está inclinada e non a vexo. Só sinto o sacho escaravellar na terra. Cando a avoa se ergue, bota fóra unha presa de herbas malas e pon as mans nos cadrís, apoiándoas nos cotenos. As mulleres de Aita nunca cospen cando traballan a terra. Os homes si. Cospen nas mans e na terra.

\section{O carro}

Case todo o mundo ten tractor en Aita. Tamén o Lucas. Pero o Lucas só traballa co tractor os festivos. A diario, vai co carro de vacas.

-Este carro fíxoo o teu avó!

O carro de Lucas canta moitísimo. Fai máis ruído ca un coche. Quero dicir que un coche fai ruído e non o escoitas. Debemos ter un aparato especial na orella para non oír coches cando non queremos. Pero o carro vén laiando e segue laiando no oído cando xa se perdeu ao lonxe.

Aí vén o Lucas coa corda nunha man e a vara noutra. Vaimo dicir.

-Este carro fíxoo o teu avó, que en paz descanse!

Des que eu era cativo, a mesma historia. Hoxe, ao ir e vir. (Rivas 2008c: 89-90)

Estamos diante de dous pequenos fragmentos separados por un título. A brevidade e o cambio de temas expresan moi ben (a forma é o fondo) os vaivéns que na mente do protagonista toxicómano provoca o consumo de droga ou a síndrome de abstinencia.

9 Aínda que compartimos con Goytisolo a orixe cinematográfica da secuenciación na novela contemporánea, esta xa existía na literatura, un exemplo poderíamos atopalo en Crime e Castigo (Dostoievski 2013: 347 e 241).

10 Unha segmentación simular, tamén introducida por títulos, podemos atopala en En bandexa de prata (Billy Wilder 1966). 
Máis próximo ao modelo habitual do cinema parece a presentación das secuencias sen ningún tipo de separación, sexa esta un título ou un espazo en branco, imitando así a unión por un simple corte.

Non fales así na casa! Rifou a nai. Cando apartaba os ollos cansos dos alfinetes da almofada, tiña a sensación de que miraba o mundo por unha celosía enreixada con punto de flor.

Falo como me sae do carallo! O mozo marchou dando un golpe coa porta que fixo pestanexar a noite.

Agora o mozo gobernaba o motor e o pai escrutaba o mar. Polo acantilado do Roncudo de Corme, na Costa da Morte, descolgábanse os outros percebeiros. Achegábase a derradeira hora da baixamar. Desde ese momento, e até que pasara a primeira hora da preamar, cada minuto era sagrado. (Rivas 2011: 152)

Reparemos en como do escenario da casa familiar os protagonistas pasan ao barco, da discusión sobre un partido de fútbol do Deportivo e o enfado do mozo ao traballo no mar, sen ningún tipo de transición, nin de espazo en branco, nin de título, como se se tratase de empalmar as secuencias dunha película simplemente cun corte.

Outro elemento estrutural esencial do cine é a montaxe. Fernando Trueba en Mi diccionario de cine opina que "desde que el cine descubrió el montaje, la literatura no ha cesado de aprender y aprender de él" (2006: 224).

García-Abad constata esta influencia da montaxe cinematográfica:

La presencia del montaje supone un recurso extraordinariamente efectivo para agilizar las transiciones de la estructura dinámica propia del cuento. Rivas incorpora a su discurso narrativo una técnica similar para ensartar situaciones que presuponen un cambio en el tiempo y en el espacio, aunque como observara Einsenstein, Griffith se había inspirado en modelos literarios para la translación al cine de este lenguaje. No obstante, si hemos de admitir que el lenguaje fílmico, sus modos de representación favorecen el montaje sucesivo de diferentes planos de la realidad, la literatura aprovecha mejor las transiciones desde la realidad al sueño o la fantasía. (2005: 109)

Vexamos como Rivas consegue adaptar con moito acerto esta técnica á súa literatura:

A sirena da ambulancia. Sorrío. O enfermeiro que me mira perplexo porque estou a sorrir.
Lola patina entre rosanovas e azaleas, nun salón de vidreiras. Vén cara min. Abrázame. É a nosa casa. E quéreme dar esa sorpresa, sobre patíns, coa saia vermella plisada abaneando canda a melena e bico da cereixa. (Rivas 2011: 98)

Este parágrafo representa unha sucesión de planos diferentes, incluso o contraplano do enfermeiro que olla cara ao ferido.

Probablemente o elemento estrutural máis importante dunha obra, polo menos dalgunhas obras, sexa a figura do narrador, a voz que conta a historia. No cine adoita acontecer, con frecuencia que o narrador heterodiexético transfire a súa ollada a un dos participantes na acción. Este proceso recibe o nome de ocularización. Genette propón o termo focalización para indicar a distancia e a perspectiva dende a que se narran os feitos. Para este autor existen tres tipos de focalización.

A focalización cero, equivalente ao narrador omnisciente tradicional; a focalización interna na que o foco coincide con un personaxe e que pode ser fixa, cando os acontecementos son sempre filtrados por un mesmo personaxe, variable, cando pasa dun personaxe a outro ou múltiple, cando depende de varios personaxes de xeito colectivo; e, focalización externa nela o narrador limítase a expresar aquilo que se pode percibir polos sentidos. Pola súa parte François Jost, cre necesario, na narración cinematográfica distinguir entre o que o narrador sabe (focalización) e o que o narrador ve (ocularización):

Nunca se reiterará lo suficiente que el cine trabaja en dos registros: puede mostrar lo que el personaje ve y decir lo que piensa. Si el análisis del film no se quiere restringir, una vez más, al estudio de la imagen, será importante diferenciar la actitud narrativa respecto al personaje-héroe en función de informaciones verbales y visuales. Atendiendo a este objetivo y para no multiplicar los neologismos conservaré (a pesar de la ambigüedad del término técnico, que, en materia de cine connota la elección de la focal) el término focalización para designar lo que un personaje sabe. Para caracterizar la relación entre lo que la cámara muestra y lo que se considera que el héroe ve, propongo hablar, en cambio, de ocularización este nombre tiene, en efecto, la ventaja de evocar lo ocular y al ojo que mira el campo que va a "tomar" la cámara. Cuando ésta parezca estar en el ojo del personaje, hablaré de ocularización interna; cuando, por el contrario, parezca estar ubicada fuera de él, utilizaré la expresión ocularización cero. (2002: 37-38) 
Vexamos como Rivas incorpora este recurso ao seu discurso:

Mira ti quen vén entrar. Mira quen chega. Non me estraña que se alporicen os morcegos. Levan meses aí, pendurados, remoendo a sombra, e xusto agora espertan. Oír si que oen, digo eu, e ese, o Malpica, xa perdeu o xeito de pisar. Quen ía pensar que acabaría de feo. Vai batendo en todos os accidentes xeográficos. Comigo están en paz. Eu son de aquí. Xa teño o niño feito. A Manequín Cega e o Esqueleto Manco non me estrañan. Nin o grou desecado. O ben que lle fixeron os ollos. Eses puntiños que miran algures, son o mesmo mirar. Do xeito que me poña, véxoos. Alucan por min. Encontrei o meu sitio. O meu zulo. Até o péndulo acouga. E xusto neste recanto, neste agocho en persiana coas lamias desaqueladas dos derradeiros libros, hai un arrecendo a arnela, nin que o mar subise aquí unha noite, ao mapa de madeira, e deixase as crebas e abelorios. A caixa coa tapa de vidro e o letreiro Malacoloxía, o choino que fundou ese nome, chea de cunchas, caramuxas e buguinas, que saquei das cuadrículas e fun pousando por aí. Había tamén coleccións de bolboretas e de escaravellos e de arañas que trouxeron da América. (Rivas 2010b: 117-118)

O narrador omnisciente cede a voz a un dos protagonistas, o drogodependente Chelín, quen nos conta o que ve, a chegada do seu antigo amigo de infancia, agora inimigo e estraño, e nos describe os restos da escola de indianos. É a ollada, a ollada concreta, inmediata, instantánea, a que nos transmite. Son os ollos do personaxe os relatores, non a súa memoria, nin o seu saber.

Un uso moi elegante e orixinal deste procedemento atopámolo nas seguintes liñas:

É un fermoso día de primavera na costa. Solleiro, mais tamén ventoso. $\mathrm{O}$ vento soán non só riza o mar senón que por vez primeira, despois do longo inverno, semella querer afastalo de terra, con refachos que peitean en aspa a superficie. Abanea os verdes todos, con vontades cruzadas. Mais é un vento que alenta luz, unha sucesión de entrelampos, o que talvez diminúe a resistencia e mobiliza a simpatía.

Todo isto vémolo coa axuda de Sira.

Vémolo a través da fiestra do cuarto principal da pousada do Ultramar. O máis grande e tamén o de mellores vistas. O que chaman A Suite. Ela está sentada nun lateral da cama. Vestida. Mentres mira, está a soltar o cabelo que levaba recollido nun moño. $\mathrm{O}$ que teñen as fiestras con mellores vistas é que tamén convocan a curiosidade daquilo que miran. E cara alí van. Ver a Sira. (Rivas 2010b: 158)
$\mathrm{O}$ fragmento figura entre as mellores páxinas do autor. $\mathrm{O}$ primeiro parágrafo parece unha descrición dun narrador externo, a vista dunha paisaxe, non obstante, no parágrafo seguinte, como se un mago mostrase o truco, nos explica que vemos a partir dos ollos de Sira. O extraordinario e sutil está en que Rivas narra dende unha protagonista pero fainos cómplices, participantes da ollada a través do uso da $4^{\mathrm{a}}$ persoa. Non é a muller quen ve, senón quen nos permite ver tamén aos lectores. A continuación, nesa deconstrución da técnica empregada, nos describe o lugar dende o que Sira observa e tamén nos xustifica o cambio (case como un contraplano) do que vai contar a continuación pois a beleza do observado provoca a curiosidade sobre o observador.

Tamén foi François Jost quen propuxo o termo auriculización para describir o "punto de vista sonoro": Se mediante a ocularización o narrador cede a palabra a un personaxe que expresa o que ve, mediante a auriculización o narrador cede a voz a quen escoita.

Si es posible caracterizar la relación del personaje con lo que muestra la cámara, parece igualmente necesario considerar cómo, en relación con el mismo personaje, opera la banda de sonido. Es notorio que la ocurrencia de un ruido o de un diálogo, como el mixaje mismo, puede anclarse en la ficción de manera más o menos subjetiva. Por ejemplo, cuando sobre la imagen de un personaje que no hable, se oye un fragmento textual o un ruido que el contexto espacial no justifica, con suma frecuencia hay que interpretar esta intervención sonora como un recuerdo o una "imaginación" del personaje. [...] A este "punto de vista sonoro", doy el nombre de auriculización. (2002: 38)

\section{Vexámolo nun exemplo literario:}

Nese intre, escoitou os ruídos. O abrir e pechar da porta principal e os pasos na sala. Quen se movía, facíao con desenvoltura, aínda que o andar e o xeito de relacionarse cos mobles era dun home rudo e de peso. O máis seguro é que fora o propio Ren, o dono da casa. $\mathrm{O}$ que convertera a súa gorida nun peculiar museo do espolio. [...] Debía ter présa o visitante. Oíu remexer papeis e pechar as portas dun armario. Logo, un silencio. Paúl Santos contivo o alento. Sabía interpretar esa clase de silencios. Son os dun home que olfactea. (Rivas 2006: 651-652)

O narrador omnisciente limita o seu coñecemento ao escoitado por Santos, agochado para non ser sorprendido na súa investigación. $\mathrm{O}$ autor podería indicarnos a variedade de 
movementos e accións de Ren dende fóra pero prefire, dotando a acción dunha maior forza emocional, contárnolo dende o único que pode percibir o intruso: os sons. Uns sons que transcenden o seu propio sentido para apropiarse do olfacto, nunha proba máis da mestría de Rivas no uso das sinestesias ${ }^{11}$.

\subsection{As características visuais}

O segundo tipo de características cinematográficas detectadas no cinema son as visuais. Os humanos percibimos a realidade, sobre todo, pola vista. A partir dela interactuamos co mundo. A percepción visual do cinema é directa, pois estamos diante dunha arte de imaxes, de luces e sombras. $\mathrm{Na}$ literatura son as palabras as que xeran a información polo que estamos obrigados a reconstruír o mencionado e incluso o evocado. Mais, se cadra, antes de mergullarnos nas influencias da sétima arte na forma das descricións literarias, sería conveniente reflexionar acerca dun dos temas de maior controversia entre os estudosos: a existencia ou non da descrición cinematográfica.

Para moitos autores como Jacques Aumont ou Marcel Martin ${ }^{12}$ no cinema non é posible, xa que esta implica una pausa no desenvolvemento dos acontecementos. Na sétima arte a imaxe flúe, non se pode deter o tempo agás nos planos conxelados que segundo eles non teñen unicamente un sentido descritivo. Por outra parte, a imaxe cinematográfica é mimética, reflicte un ente real, de modo que non vemos un can, senón "este can", o que implica que o control estético do obxecto filmado nunca pode ser absoluto pois non é estritamente unha creación senón unha elección. Ademais, apunta Seymour Chatman (apud Becerra 2003: 49), o carácter do filmado é case ilimitado, a totalidade dos detalles presentes é imposible de percibir polo espectador no rápido transcorrer dos fotogramas.

Se cadra, como defende Carmen Becerra:

El problema obtendría una menor resonancia si no perdiéramos de vista que nos hallamos ante dos lenguajes diferentes; en consecuencia no puede pretenderse que un sistema de análisis creado para estudiar una obra literaria, por tanto un código exclusivamente verbal, puede aplicarse sin alteraciones al estudio de las obras pluricódicas, como la narración cinematográfica. (Ibid. 51)

Como acabamos de comentar, Chatman, no seu traballo de 1978, postulouse en contra da existencia da descrición nas producións audiovisuais, mais en investigacións posteriores mudará a súa posición. Na súa opinión, debemos considerar dous tipos de descricións: explícita e tácita, esta última sería a propia da arte audiovisual. Se a imaxe, coa súa capacidade de abarcar todos os detalles, era vista anteriormente como un impedimento, agora é considerada por este investigador como a proba da existencia desa modalidade tácita:

El film nos proporciona una plenitud sin especificidad. Las descripciones, que ofrece son a la vez, visualmente ricas y verbalmente pobres. A no ser que sean suplementadas por redundancias en el diálogo de la narración de la voz en off, las imágenes cinemáticas no pueden garantizar su posibilidad para nombrar rasgos de información descriptiva. Contrariamente, la narración literaria puede ser precisa, pero siempre dentro de un campo relativamente limitado. Siempre quedan "agujeros" ocultos. La descripción verbal puede, pero nunca lo hace, abarcar la multitud de detalles disponible en una fotografía. (apud Becerra 2003: 50)

Por outra parte o cinema pode deter o tempo non unicamente co plano conxelado senón tamén, por exemplo, mediante o emprego dunha montaxe que implique unha relación de simultaneidade e non de sucesión.

Carmen Becerra defende, seguindo a Genette, que, aínda que consideremos, con todos os matices que se queiran, a literatura como unha arte temporal e o cine como unha arte espacial, isto non implica necesariamente que as descricións literarias impliquen unha pausa temporal:

Así pues, la descripción sólo supondría una suspensión temporal, si fuese llevada a cabo por un narrador externo, un narrador que no es personaje, pero si el fragmento descriptivo es el resultado de la acción de contemplar de un personaje, el tiempo de la historia seguiría discurriendo sin interrupciones. Si aceptamos esta premisa podríamos afirmar que, al menos en

11 Para os curiosos diremos que este procedemento xa fora empregado con anterioridade na literatura, por exemplo, Jane Austen en Sentido e sensibilidade (2015: 271 e ss.).

12 Citados en Carmen Becerra 2003: 49. 
estos casos, el argumento de la pausa temporal para negar las posibilidades descriptivas del cine, no sería válido. (2003: 52)

Esta investigadora sostén, seguindo a Hamon, que toda descrición consta de unha denominación -elemento descrito, non sempre explícito-, unha expansión -o listado de termos coordinados ou subordinados- seguida de predicados que indican as propiedades dos elementos da expansión. Sucede que a literatura para describir unha vivenda, poñamos por caso, enumera os seus atributos, o cine, en cambio, emprega, por exemplo, un plano xeral seguido de distintos planos detalle. Non obstante, conclúe:

Es cierto que lo que obtiene el espectador con un plano general del espacio, no es igual al que obtiene el lector con la lectura y posterior imagen mental que el pantónimo suscita; sin embargo ambas imágenes son equiparables en cuanto a su generalidad y distintas sólo en su concreción. Para el espectador, la realidad de ese espacio es física, precisa y concreta, además de ser el mismo espacio para todos los espectadores de la misma imagen (esto último con matizaciones). Para el lector es una imagen mental, abstracta, que adquiere concreción en su mente en virtud de su experiencia y sensibilidad previas; además de que tal imagen, generada por la palabra, es diferente para cada uno de los lectores de la misma. Pero de las diferencias que provocan uno y otro código -el verbal y el visual- no puede deducirse la imposibilidad del segundo para la modalidad descriptiva, sino sólo su distinta naturaleza. (Ibid. 52-53)

En resumo, compartimos con Carmen Becerra que "a) El cine puede describir igual que la literatura; b) como en literatura la descripción no genera necesariamente una pausa temporal y c) no se puede trasladar un modelo de análisis creado para un sistema a otro sistema diferente, sin provocar problemas o errores" (Ibid. $55)$.

Resta, non obstante, un último obstáculo que cremos debe ser tamén rebatido ou cando menos matizado. A idea de que o cinema non reflicte un can senón "este can". Nas distintas versións de Lassie, o personaxe da cadela foi interpretada por diversos animais sen que isto presentase ningunha anomalía na narración nin para os espectadores, porque en realidade non se representa "esta cadela", entendida como ser real, como individuo, senón "esta cadela", entendida como personaxe -nisto no difire de Ulises, don Quixote, Joseph K, ou Cibrán- e, polo tanto, abondaba con que tivesen un aspecto semellante porque o importante é a verosimilitude non o mimetismo.

Se os obstáculos da pausa temporal ou da natureza mimética da linguaxe cinematográfica non existen, queda a tarefa de descubrir que procedementos emprega o cinema para realizala. Atrevémonos a propoñer, a modo de aproximación e sen ánimo exhaustivo, os seguintes.

A voz en off pode deter a acción e describirnos un lugar, unha persoa, un tempo, etc., cos mesmos trazos que un texto literario. Con anterioridade citabamos o comezo de Manhattan (Woody Allen, 1979). O narrador simula estar a escribir un libro sobre Nova Iorque e escoitamos as distintas propostas que xorden da súa mente. Acompañando este pensar van aparecendo imaxes da citade que representan mimeticamente o relata dono texto oral. Certamente o detalle visual da imaxe supera á do discurso pero, aos ollos do espectador, o retratado preséntase como o fiel reflexo do comentado e todas as accións reflectidas: o camiñar, o fumar, etc., dos figurantes están subordinadas ao proceso de descrición da Grande Urbe e, son, en certo modo, invisibles.

Algúns cineastas conseguen que a voz da conciencia se encarne visualmente nos fotogramas. Se analizamos o comezo de Annie Hall (Woody Allen, 1977), observamos como Alvy Singer (Woody Allen) retrocede a súa infancia e describe os seus profesores e compañeiros:

Lembro os profesores da nosa escola pública, tiñamos un dito: "os que non saben ensinan e os que saben ensinar dan clase de ximnasia, e os que non sabían nada de nada mandábannos a nosa escola", sempre pensei que os meus compañeiros eran parvos de todo... ${ }^{13}$

A acción está completamente detida, só existe na mente do narrador homodiexético. Esta parálise temporal vese reforzada polo feito de que o personaxe narrador, nunha clara homenaxe a Bergman, aparece na aula simultaneamente, pero non nos mesmos fotogramas, (non esquezamos que estamos a contemplar un

13 A tradución é nosa. 
pensamento) co aspecto infantil e co aspecto adulto. A escena é unha pura descrición da clase e dos seus integrantes, por máis que se narre algunha peripecia.

Este proceso de pausa é aínda máis claro no comezo de Bienvenido Mr. Marshall. Luis García Berlanga non só emprega a voz en off, non só conxela a imaxe, con todo o que isto implica, senón que deliberadamente comeza o proceso de descrición mediante a eliminación dos personaxes da escena.

\begin{abstract}
Érase una vez un pueblo español. Un pueblecito cualquiera y sucedió que una mañana, precisamente esta mañana, cuando el..., pero no. Creo que deben ustedes familiarizarse con sus casas, sus habitantes y sus costumbres antes de que ocurra, bueno antes de que ocurra lo que va ocurrir de un momento a otro. No sería mejor pararlo todo un poco tiempo. Es martes, ya está ${ }^{14}$. Como ustedes pueden ver este pueblo no tiene nada de particular. Fíjense en la plaza, perdón ${ }^{15}$. Asi hay menos estorbo ${ }^{16}$. Las cosas más importantes ocurren aquí: los bailes, los mercados, las corridas de toros, las noches de luna... La fuente ${ }^{17}$ es muy antigua, y el agua, cuando sale, es buena y fresca. La iglesia es bastante vieja. Exactamente data del mil tres... bueno el caso es que es viejísima y los entendidos dicen que tiene un gran mérito, ellos sabrán por qué. Este es el ayuntamiento, con su balcón y todo, para que el alcalde pronuncie desde él elocuentes discursos y este es el reloj. No, no son las tres y diez, está roto y claro hasta que haya fondos para arreglarlo. Aquí la escuela.
\end{abstract}

A descrición do pobo e logo dos habitantes, que continúa durante bastante tempo, non ofrece dúbida, aínda que empreguemos os máis severos criterios.

Un segundo procedemento podemos atopalo no plano xeral. Se contemplamos os catro minutos iniciais de Midnight in París (Woody Allen, 2011), non atoparemos ningún feito, só fermosísimas imaxes da Cidade da Luz. Allen, nunha homenaxe aos impresionistas, móstranos a cidade a distintas horas do día e en distintas situacións atmosféricas. Non hai acción só unha recreación na beleza da capital francesa.

Certamente un fotograma do Monument Valley ou da taiga siberiana contén milleiros de matices -iso si, por máis que se insista, imperceptibles na proxección a vinte e catro fotogramas por segundo- que superan calquera descrición literaria posible do mesmo pois precisariamos de centos de palabras para expresar todos os matices aí comprendidos. Non obstante, cando Kurosawa nos mostra en Derzú Uzalá (1975) a taiga, observada dende a posición do capitán Arséniev, non pretende que identifiquemos cada folla de árbore, senón que contemplemos e sintamos a beleza da paisaxe e tamén a dificultade de ver, naquela mestura selvática, sen os ollos apropiados de Derzú; é dicir, pretende describir.

Pero o plano xeral non é o único con capacidade descritiva, tamén o plano detalle ten a capacidade de mostrar a realidade. Pensemos, por exemplo, no espello roto de $O$ apartamento (Billy Wilder, 1960) ou no plano do caderno do capitán Arséniev da xa citada Derzú Uzalá (Akira Kurosawa, 1975); o debuxo móstranos como o cazador construíu a cabana. A acción xa rematou, o plano detén o tempo coa única misión de comunicar ao espectador o talento do protagonista: unha pura descrición.

$\mathrm{Na}$ nosa opinión a montaxe tamén pode converterse nun recurso descritivo. Deteñámonos por exemplo na escena da festa de fin de ano en A quimera do ouro (Charles Chaplin, 1925). No momento da canción observamos un plano xeral, lixeiramente picado $-\mathrm{o}$ que xa denota de por si a condición de derrotados dos asistentes á festa. Os protagonistas ábrense creando un círculo na pista de baile. Nese momento o plano cambia e a cámara realiza un movemento panorámico, no que se van inxerir varios planos detalle. Certo que a interpretación da canción non se detén, pero os rostros dos personaxes, mostrados neses planos detalle, especialmente o da muller maior, o da moza que chora e o do home que fuma en pipa, sen negar o seu valor expresivo, aportan unha descrición do seu estado de ánimo, e, por contraste, da dureza do paso do tempo. A acción de cantar é superflua e o único que chega ao corazón do espectador son os sentimentos a partir da descrición dun espazo e dun tempo. Nin sequera a acción paralela do homiño na súa caseta rompe esa intención ou cando menos

\footnotetext{
Neste momento a imaxe se conxela.

Neste momento o director, mantendo o plano conxelado, elimina os personaxes.

Os itálicos son nosos.

A partir de aquí o director emprega planos dos obxectos descritos.
} 
esa sensación descritiva pois del tamén se nos mostran os sentimentos de soidade e tristura.

Tamén a banda sonora ${ }^{18}$, por veces, persegue e acada valores descritivos. Se observamos detidamente o comezo de Moito ruído e poucas noces (Kenneth Branagh, 1993), contemplamos como o director ralentiza a velocidade de proxección dos planos dos cabalos cabalgando, o que contrasta coa velocidade do resto das accións dos mozos e mozas que están desexosos de atoparse. Estes diferentes ritmos serven para presentar os personaxes. A música subliña as súas accións, de feito, os acordes máis altos da mesma coinciden coa subida no ritmo do cabalgar e os máis baixos co descenso dos xinetes. En Benvido Mr. Chance (Hal Ashby, 1979) o realizador emprega a música para describir a posición do protagonista no mundo. Para iso válese da intertextualidade. Ao igual que Kubrick en 2001, unha odisea no espazo (1968), emprega os acordes de "Así falaba Zaratrusta" de Richard Strauss, pero, mentres no filme de ciencia-ficción a música servía para acentuar a idea de que homo homini lupus -o primeiro signo de intelixencia do home é o emprego dunha arma para matar un inimigo-, Mr. Chance é un home inxenuo, un home bo por natureza, illado da sociedade, carece de toda maldade. Para marcar este cambio Ashby emprega a peza de Strauss con arranxos ao estilo funki.

Por último atrévome a suxerir outro tipo de descrición ata agora non comentada: a etopea. Para ilustralo comentaremos a escena de $A$ lexión invencible (John Ford, 1949), na que Nathan Brittles vai regar as flores da tumba da súa dona. Rodada ao anoitecer, non conta realmente nada, as palabras do protagonista non fan máis que repetir o que o espectador xa sabe, a acción de regar, resulta completamente prescindible e, por suposto, allea á trama principal. O obxectivo da secuencia é exclusivamente mostrar os sentimentos do protagonista, o seu amor máis alá da morte pola súa muller. Ford detén a acción, para penetrar na personalidade do aparentemente rudo capitán.

Se cadra, non está na man do director nin do espectador deter o tempo, pero si a de sentir, a de percibir, e por máis que os ilimitados fotogramas fuxan; a de poder reter na mente aqueles aspectos significativos que lle sirvan para comprender a historia, para debuxar o lugar e os seres que o habitan, abstraéndose, moitas veces, das concrecións e dos rostros que nos serven para visitalas.

Mais volvamos ao rego da literatura. Como xa comentaramos os estudosos sosteñen que unha das características cinematográficas fundamentais dos textos literarios son as descricións "eminentemente visuales" (Antón 2007: $240)^{19}$. Non debería sorprendernos pois a vista parece o sentido máis empregado polo ser humano, polo tanto, non é de estrañar que sempre, non só despois da aparición do cinema, as descricións literarias sexan, sobre todo visuais. Mais se analizamos segmentos como o que segue a filiación cinematográfica é innegable:

E foron os seus ollos unha cámara lenta para ver como Lousame saltaba en arco limpamente e trincaba ao sentenciado entre as garras. Aínda que afeito ás escenas de caza, arrepiou esta vez ante a inminencia do despezamento, triste réquiem para un ministro, pois ao cabo colléralle agarimo a aquel gobernador de vidas e de almas que loitaba no fondo contra si mesmo. E imaxinaba xa ao gaiteiro libertario arrincándolle de entrada o corazón, demorándose en mastigar a víscera dos sentimentos, pois son as vinganzas os máis crueis escarnios que o pensamento pode debuxar. Ou poida que non. Estaba quedo, manténdoo apreixado pero sen miralo. Poida que estea a matinar en algo máis terríbel que tamén se ensaiara cos pesadelos da guerra nos foxos de Néboa: meterlle na boca os collóns arrincados en vivo, esperta aínda a intelixencia da vítima. (Rivas 2008a: 121)

A escena de caza está descrita, contemplada, como unha cámara de cine, en concreto unha cámara lenta. $\mathrm{O}$ personaxe (repárese na ocularización) observa o salto, a acción de trinca, o despezamento, o proceso de arrincar as vísceras, a demora na mastigación.

Por que será que a aldea é máis escura? Sempre luz aquí, na cidade. Mellor ir cara ao centro. Entre grandes edificios, unha casiña de galerías deshabitada, convertida en pombal. [...] Nos xardíns do Cantón, un xardineiro escribe con mirtos un calendario na terra. 24, xullo, 1991. O

18 Debo esta idea a Carmen Becerra Suárez quen non só ma mostrou senón que me comentou o primeiro dos exemplos que fornezo. Por suposto son os responsable das deficiencias da exposición desta idea.

19 No fondo non deixa de ser unha manifestación da evidentia ou demonstratio. 
estanque dos peixes dourados. O monumento da aguia e das cadeas. Alí pon Concepción Arenal. Axudaba aos presos. Cal era a outra? Rosalía. Claro. Rosalía de Castro. E aquela máis gorda? Cruzar por aquí, onda o Banco Pastor. A gordiña era Pardo Bazán. A mestra, dona Carmen, dicía tamén: Juana de Vega, casada con Espoz y Mina, héroe de la Independencia, le bordaba las banderas, guardó su corazón en un frasco de formol. O reloxo do Obelisco: xa case son as once. Seguro que era o corazón. Poñeríase branco. (Rivas 2008a: 123)

O narrador, como se dun filme de Hitchcock se tratase, móstranos dende unha fiestra (un plano picado) parte da cidade da Coruña: os grandes edificios, a casiña, os xardíns do Cantón, os distintos monumentos. A ollada ademais implica un movemento panorámico.

A cámara mediante o encadre, entendido como selección espacial, acouta a realidade que abarca. O director pode aproveitar esta inevitable limitación física para expresar un significado determinado. En The bridge on the river Kwai (1957), David Lean roda a escena da chegada dos prisioneiros británicos de xeito que, ao final da mesma, as pernas do coronel Saito (Sessue Hayakawa) formen unha arcada debaixo da cal aparecerá enmarcado o coronel Nicholson (Alec Guinness), mostrando así o poder do primeiro sobre o segundo; fisicamente baixo as súas botas.

Todos os encadres conforman un tipo determinado de plano. Definir un plano non é tarefa sinxela; Vicente J. Benet opina que:

El plano es más complejo de definir, entre otras cosas porque tiene distintos valores. [...] En primer lugar el plano se identifica con la "toma" durante el rodaje, es decir, el trozo de película impresionado cada vez que se pone en marcha la cámara hasta que se detiene. En segundo lugar, estos planos son en muchas ocasiones descompuestos, fragmentados y recompuestos en la tarea del montaje, por lo que el plano pasa a convertirse en el fragmento entre dos cortes efectuados en la mesa del montador. En tercer lugar, un plano es también una unidad de segmentación en el análisis de un filme, un elemento que sirve para unificar la disparidad de componentes que pueden encontrarse en la imagen. (2007: 214)

Neste momento centrarémonos no último dos sentidos. Clasificaremos os planos en: xeral (permite observar un espazo amplo, unha paisaxe, un decorado), plano enteiro (representa unha persoa da cabeza aos pés), plano americano (representa un ser humano dos xeonllos á cabeza), plano medio (mostra a metade dunha persoa, de cintura ou de embigo para arriba), primeiro plano (mostra o rostro ou unha parte concreta do corpo dunha persoa) e plano detalle (ensina un obxecto moi pequeno ou unha parte del).

$\mathrm{Na}$ literatura non se mostra toda esta variedade de planos, carece de importancia mostrar a diferenza entre un plano enteiro ou un plano americano e mesmo resulta difícil distinguir primeiro plano e plano detalle. Non pretendemos daquela reflectir un repertorio completo de todos estes planos da sétima arte na literatura, máis si achegarnos algúns exemplos para ver a influencia da imaxe fílmica nas letras

Cando falabamos da descrición cinematográfica xa explicamos como o plano xeral podía ser ademais dunha indicación do lugar onde se realizaba a acción, o transmisor doutras informacións asociadas, a pequenez do home ante a natureza hostil, a dificultade para interpretar o mundo... Iso mesmo podemos atopalo en exemplos literarios:

As primeiras fogueiras dos libros foran dispostas alí, a carón da Dársena, camiño do Parrote. Por dicilo así, no ventre urbano, onde o mar pariu a cidade, o primeiro niño de pescadores, e xa medrou moito a herba dende entón, mesmo nos tellados, que teñen vocación de verde enfesta, nese lugar que hoxe é centro onde conflúe o transporte das lanchas da baía, os tranvías urbanos e os coches de liña do interior. As outras fogueiras arden alí ao lado, na praza maior, que leva o nome de María Pita, a heroína que encabezou a defensa da cidade nun dos moitos ataques por mar e á fronte dun comando de mulleres pescantinas, e onde agora está situado o pazo municipal coa lenda de "Cabeza, Garda, Chave e Antemural do Reino de Galicia". (Rivas 2006: 56-57)

Estamos diante dun plano xeral, un lugar e unhas fogueiras que arden; contemplado todo o conxunto por un espectador. Ademais o autor preséntanos este espazo non como unha fotografía parada senón como un recinto "en movemento" no que están a acontecer actos e máis actos, ás veces, nin sequera simultáneos: queimar os libros, arribar as barcas, chegar os tranvías. A mobilidade provocada por estas actividades reflicte perfectamente as imaxes do cinema. Dalgunha maneira estamos ante o espello literario do comezo xa citado de Bienvenido Mr. Marshall, se no filme de Berlanga o director detén a imaxe e a literaturiza, Rivas intenta describir a mobilidade, axilizar o texto para, como nas obras arquitectónicas do barroco, intentar simular que se moven. Podemos 
detectar tamén, un movemento panorámico, o movemento da ollada para, tamén nun plano xeral, mostrar a praza do concello.

O plano enteiro, como xa quedou comentado, describe unha persoa da cabeza aos pés. Resulta evidente que a simultaneidade perceptiva do cinema non é posible, agás que consideremos o uso dun adxectivo: "Era un home moi rexo" (2011: 118) como manifestación dun plano enteiro cando este dá conta da totalidade. Non obstante, existen descricións máis minuciosas que dan conta do plano enteiro:

Era unha das cousas que impresionaban de Arturo da Silva, o campión dos pesos lixeiros de Galicia, que tiña a cabeza chea de metáforas. Non era coñecido por iso, senón polo seu gancho, temido como unha cobra, e por como se movía, aquel danzar incansable, durante os combates. O seu célebre xogo de pernas. (Rivas 2006: 65)

Dende a cabeza, máis que un elemento físico, depositaria dun estilo, pasando polas mans, expresadas metonimicamente (o seu gancho) ata as pernas que bailaban no ring, a descrición do todo é completa.

Habitualmente o plano medio é o menos enfático de todos os planos, nin nos mostra ao protagonista diminuído ante un mundo que o abarca pero o supera, nin na emoción do primeiro plano ou do plano detalle. Non obstante, acompañado das vestimentas, dos xestos dos actores, etc., poden transmitir unha grande intensidade. Abonda con observar os distintos planos medios dos almorzos do matrimonio Kane na película de Welles para comprobar como "ao cabo de quince días eran un matrimonio como calquera outro". Os sorrisos iniciais acaban por ser substituídos por rostros adustos e, por último, en rostros que non se ven, que se agochan detrás do xornal. A vestimenta da actriz, alegre ao principio, vaise convertendo cada vez en máis vitoriana e formal. A xenialidade de Welles estriba en que non precisa para nada de planos enfáticos para mostrarnos a decadencia matrimonial.

Pero volvamos á obra de Rivas e comprobemos como emprega un plano medio:
A señorita Vacaburra, definitivamente, ten un tipo extraordinario. Creo que vai moi lixeira por debaixo da bata e as tetas son estilo recordwoman. Ten a cara redondeada, o pelo curto, algo rizado, e uns ollos moi grandes e con moita luz, desa que brilla nos campos mollados. (Rivas 2008c: 26)

O narrador protagonista describe á enfermeira que o atende, de cintura para arriba: os seos, a cara, o pelo. Reparemos en que, para describila emprega a imaxe das azafatas dos programas de televisión as recordwoman, unha vez máis a imaxe dentro da imaxe.

María Teresa García-Abad apunta o uso do primeiro plano característico do cinema:

O fervor ${ }^{20}$ facía bailar a tapa da pota. Daquela boca mutante saían bafaradas de vapor e gargallos de escuma verde. Unha avelaíña revoaba no teito arredor da lámpada eléctrica que colgaba do cable trenzado. Mamá estaba enfurruñada como cada vez que tiña que pasar o ferro. A súa cara tensábase cando marcaba a raia das perneiras. Mais agora falaba nun ton suave e algo triste, como se se referise a un desvalido. (Rivas 2011: 106)

\section{E comenta:}

Einsenstein en su teoría cinematográfica vislumbra la presencia del cine o al menos de lo que se ha dado en llamar mirada precinematográfica en la novela victoriana de donde "nacen los primeros brotes del film americano estético, para siempre ligados al nombre de David Wark Griffith", como el mismo director había reconocido (Einsenstein, 2002: 249). Se trata de una relación orgánica que establece una línea genésica de descendencia más que posible. El comienzo de El grillo del hogar de Dickens sirve de elocuente ejemplo sobre modos posibles de dar comienzo a una novela, pero también aporta visualmente la construcción de un primer plano típico del cine de Griffith: "Fue el puchero el que empezó...". Del mismo modo, que la transición entre el diálogo de Moncho con su madre tras el primer día de clase y la conclusión derivada de sus explicaciones sobre la existencia del demonio, "era un ángel, pero se hizo malo".

20 A propia García-Abad fai fincapé na polisemia fervor remitindo a un texto de Rivas do conto "A leiteira de Veermer", incluído no mesmo libro: "Diante daquel cadro de misterioso fervor, a verdadeira representación da sagrada familia, reprimín o impulso de poñerme de xeonllos. Tiven medo de chamar a atención como un turista excéntrico, deses que pasean por unha catedral con lentes de sol e pantalón bermudas. En castelán hai dúas verbas: hervor e fervor. En galego só hai unha: fervor" (2005: 128). De modo que o fervor da pota, é tamén o fervor da nai, a relixiosidade tamén se mostra no seu quefacer. 
O emprego de Rivas destes primeiros planos de xeito consciente queda demostrado polo uso do termo:

O balbordo apágase. Os dous en primeiro plano ${ }^{21}$. Preto do estanco, que fai esquina. Filmándose con intensa demora. Nada de bágoas. Se filmas, non choras. Nada de abrazos. Levan as mans ocupadas, e ademais... Os extras que non miren á cámara! Só a estanqueira. (Rivas 2011: 428)

Primeiros planos de escuma e guiguirai de ondas. (Rivas 2003: 18)

O plano detalle mostra unha parte pequena do corpo ou ben nun obxecto tamén de reducidas dimensións e, en xeral, serve para acentuar a emoción do narrado, pensemos, por exemplo, no plano detalle do zapato de Harry Lime (Orson Welles) en $O$ terceiro home (Carol Reed, 1949) mentres se escoita a voz de Anna Schmidt (Alida Valli) dicindo: "foi mellor que morrera". O descoñecemento da identidade do portador dos zapatos, asociada co comentario coloca ao espectador nun labirinto de emocións.

Cando a luz da cociña se apaga, afrouxan os fíos dos corpos e o lume da lareira prende nos ollos coma un feitizo. As chamas das achas máis pequenas agatuñan pola códea do toro, bican nel como linguas de serpe e vano envolvendo nun abrazo triunfal e devorador. Cada pau consúmense nun fogo lixeiramente distinto. O marelo ten corazón vermello e ás azuis de puntiñas brancas. Que cor darán os corpos ao arderen? (Rivas 2008c: 110)

O texto móstranos conxunto de planos detalles: o toro, as lapas, as achas, o pau. Concentra a nosa ollada nas pequenas linguas de fogo que se forman na lareira.

Cando vexan un espectro, procuren fixarse nas súas mans. En concreto, nos seus cotobelos. Como o predicador falso d'A noite do cazador que interpretou Robert Mitchum, hainos que levan tatuada nunha man a palabra amor, e na outra, odio. (Rivas 2008b: 155)

De novo atopamos outro fragmento empapado de cine, non só o plano detalle dos cotobelos senón que estes están tatuados ao xeito do personaxe dun filme.

Remataremos este apartado cunha mención ao plano conxelado por ser citado expresamente polo autor. O plano conxelado transcende a función de simple pausa narrativa para adquirir outros significados asociados. Neste sentido resulta moi interesante analizar o remate de La lengua de las mariposas (José Luis Cuerda, 1999). O director decide acabar a película, despois de que o neno comece a insultar o mestre chamándolle "rojo" e "ateo", conxelando a imaxe no intre en que lle chama "tilonorrinco e espiritrompa". Este remate deixa o espectador diante dun final aberto, cuxo significado ten que interpretar pois non sabe se é unha continuidade nos insultos ou unha homenaxe. $\mathrm{Na}$ literatura, a mención deste tipo de plano non deixa de ser un xesto de complicidade de autor cinéfilo a lector cinéfilo.

Aqueles dous nenos que un día foran amigos desapareceron polo sumidoiro da memoria, que o mesmo serve para lembrar que para esquecer. Para o Chemín vello tombado no leito só ficaba daquel tempo, como imaxe conxelada, o brillo húmido do arco da vella na pel dos arnais. (Rivas 2011: 210)

O feito de que o vello, despois de anos de ruptura da amizade con Gandón, o compañeiro de xogos infantís, asuma aquela relación non como unha imaxe viva, de presente, senón como estática, inmóbil expresa (a forma é o fondo) a imposibilidade de revivir aquela amizade infantil.

No principio o cineasta ocupábase só de colocar a cámara nun lugar onde toda a acción puidese ser capturada. En certo modo o aparato semellaba a posición dun espectador dunha obra de teatro. O descubrimento da montaxe permitiu colocar o dispositivo en distintos emprazamentos para dar distintas visións dunha mesma acción e tamén permitiu variar a lonxitude do plano. A evolución do cinema foi aínda máis alá pois a cámara deixou de estar fixa e pasou a ter movemento. Analicemos a continuación como os principais movementos acaban por se reflectir na literatura.

A panorámica consiste nun movemento da cámara sobre un eixo. Este desprazamento pode ser vertical, de arriba a abaixo ou viceversa, ou horizontal, de dereita a esquerda ou viceversa. É claro que estes movementos semellan moito aos procedementos tradicionais de descrición, como non podería ser doutro xeito, xa que se corresponde co desprazamento natural dos nosos

21 Todos os itálicos do texto, agás que se faga constar de xeito expreso, son nosos. 
ollos e, eventualmente do noso pescozo, en calquera ollada. Non obstante, veremos como Rivas describe as panorámicas e como se reflicte a filiación cinematográfica da mesma:

\begin{abstract}
Algúns só escoitan ese chasquido final dun nome propio. Un nome que provoca unha certa conmoción, pois os falanxistas que están a carón do camarada máis fornido, o que fixo a pregunta, imítano e colocan a man a xeito de viseira contra o sol para ver mellor, aínda que non todos esculcan na mesma dirección, alí onde Curtis está parado, senón que xiran e miran en panorámica, tamén cara aos tellados, como se o nome aquel evocara algo indeterminado. Non unha persoa exactamente, senón un fenómeno da atmosfera. Curtis sabe que non ten que moverse. El é a lebre. El é o que ten máis área de visión. Por iso fai sol, que sitúa os outros nunha área de cegueira. Por iso fai ben en non moverse. Calquera movemento brusco delataríao e precipitaría os acontecementos. De pelexar ao ar libre, de pelexar coa luz natural, dixéralle Arturo da Silva, o primeiro que tes que facer é procurares o apoio do sol. Que o sol estea do teu lado. (Rivas 2006: 135)
\end{abstract}

A palabra "panorámica" vén a demostrar que o autor ten conciencia de estar a desenvolver unha descrición como á do cinema. O movemento das olladas dos falanxistas dende os tellados ata o lugar das fogueiras imita o desprazamento dunha cámara e tamén denota o intento de rexistrar, de recoller, calquera detalle sospeitoso.

Cada camiño ten a súa imaxinación. Os camiños morren cando deixan de contar historias. Este camiño de que falo estaba cegado pola vexetación gran parte do ano. Caera en desuso. Ademais nós viviamos afastados de alí, na outra banda. $\mathrm{E}$ non obstante, o meu ollar prendeu nel: lembro un día de inverno, chuvioso, na curva apareceu a comitiva dun enterro. Este filme do camiño non era de todo estraño. Mesoiro e Feáns pertencían á parroquia de San Vicenzo de Elviña e traían a enterrar os seus mortos, moitas veces a pé, coa caixa nos ombreiros durante quilómetros. Mais ese día o camiño cego abriuse para amosar o andar extremo da tristura. Movéndose nunha orde pesarosa e apiñada, alzados os paraugas negros como escudos alcatranados contra o ceo de chumbo, a comitiva fúnebre avanzaba. E o que levaban era un cadaleito pequeno e branco. Cando morría unha crianza, era un anxo quen morría. Mais a min daquel día, non sei o porqué, quedoume a impresión de que era Deus o que morrera. (Rivas 2012: 102)

De novo a pegada do cine é innegable, Rivas describe o "filme do camiño" cunha panorámica que acompaña o pasar dos personaxes. Reparemos, ademais, que a mestura de planos xerais (a comitiva) e planos detalle (o do cadaleito) remite á montaxe.

O travelling consiste nun desprazamento de cámara a través de calquera medio que a transporte. $\mathrm{O}$ máis antigo que coñecemos foi rodado polo equipo dos irmáns Lumière en Venecia sobre unha góndola. Un uso moi orixinal deste procedemento na obra de Rivas podemos contemplalo no seguinte parágrafo:

O meu nome é Santa Cristina, do transporte marítimo de viaxeiros na baía. É un día de verán, pola tardiña. Estou atravesar a baía. De volta da praia, no atardecer, estarei ateigada de bañistas, mais agora, na ida, vou case baleira. En popa, a estribor, apoiado na varanda e ollando a cidade da que nos afastamos, vai un home cun traxe branco, de tea lixeira, de feitura tan folgada que a brisa forma parte do corpo e da vestimenta. $\mathrm{Na}$ outra banda, a babor, mirando na mesma dirección, hai unha muller cun vestido de gasa de seda azul mariño estampado de lazos. Co brazo dereito cingue o vestido, pola saia, ás coxas, así que a brisa forma parte máis ben do seu pelo. Un pouco máis atrás, sentado, con camiseta de raias horizontais brancas e azuis e pantalón curto vai un rapaz duns oito anos sumido no tremor da agulla dun compás. Ergue a vista e berra cara á muller. Imos de Oeste a Leste! Sorrí orgulloso polo informe. Este é o único intre en que as miradas do home e da muller se cruzan e manteñen durante un tempo. Tamén sorrín. Cada atraco no desembarcadoiro de pedra, a muller e o neno baixan de primeiros e andan máis aló da rampla lousada por diante da fileira das policromadas casetas de baño. O home camiña a distancia. Leva a chaqueta dobrada no brazo, e a camisa branca, de manga curta, desabotoada no peito, devólvelle realidade ao seu corpo. Hai un quiosco de madeiras con refrescos e xeados. Alí alugan as casetas e a muller paga, toma a chave e volve sobre os seus pasos. (Rivas 2006: 537-538)

O texto está cheo de matices e de recursos, empezando pola personificación do narrador: un barco. O observador cambia de ollada: cara ao home, cara á muller, cara ao neno. Trátase dunha mirada inestable, azarosa, como se fose de aquí para ala, imitando o proceder dunha cámara subxectiva. A continuación aparece o travelling; observamos a cidade da que se afasta e logo a praia á que arriban, unha descrición realizada dende un obxecto en movemento. Por último a ollada dos acontecementos do areal, semella un zoom que perseguise aos protagonistas. Vémolos sempre como de cerca pero xa non o están pois o barco permanece 
no embarcadoiro, isto só se explica porque a ollada, como a cámara se adapta á distancia.

Mediante da cámara ao ombreiro, o director pretende imitar a inconsistencia e a subxectividade da ollada humana, que se move bruscamente dun lugar a outro, sen a obriga de obter unha lóxica ou un enfoque correctos. Consideremos agora o seguinte exemplo literario:

E cando viña a noite leonada, prendidas da televisión as cansas liñaxes da aldea, moito gustaba a señora de espirse no dormitorio a carón dun braseiro ben vivo, por se algún día se lle quentaban os pés, que andaba nos invernos con medias e tres pares de carpíns sen que baixase o sangue ás dedas, que non era cousa da vellez, que xa de nena, antes de ir ao leito, lavábanllos en auga fervida sen nunca escaldar, e logo aínda lle pasaban o ferro polas sabas, mais cando espertaba xa non notaba os pés pola friaxe e tiñan que lle dar fregas a man para que volvese a cor e pousar neles. Ser era unha cousa de familia, pois era de andar fresca polo resto e sentía como intenso ese pracer de agora, o lambido frío do lobo da noite polas costas, as agarimosas linguas da calor que engatan por diante, devagar, cinguíndose como hedras ardorosas polas coxas, e, apuxando cadeiras arriba, gabean polos seos e neles enredan co bico dos beizos até que se poñen tesos, non á maneira de antano senón máis recreada, como loto ou camelia, e logo aganchan no pescozo e beixan toda a cara, primeiro en delicado, despois ao tolo, cos dedos do lume enredados nas guedellas, suxeitándoas entrelazadas na caluga, pois ela dobra e abaixa cara ao amante, rotando a cabeza cos ollos pechos. E cando xirou, como de súpeto, volveu apoiar as mans nos xeonllos e dobrou de tal maneira que as follas de pan ouro prendían trementes pola nádegas. Mais foi ver e non ver, porque agora, como se perdese o fío dun soño, estira o corpo e abana a cabeza, peiteándose de pasada cos dedos, e moi axiña, véndolle os dentes á friaxe, pon un pixama de flanela que a Don Xil de Arán lle pareceu de feitura de home, aínda que non puido reparar moito nese pormenor porque a señora se achega ao tocador e prende a lámpada.

O estalido de luz deixouno atordado e Don Xil, en lugar de fuxir por onde viñera, ficou encollido contra a base do espello, que era esmerilado en cisnes todo á beira, xusto detrás dunha caixiña de cartón en que se vía unha fermosa muller cunha xoia furada no nariz, que ben podería chamarse Nostalxia polo mirar, mais o que alí puña era Henna of Pakistan, protexido tamén da vista da señora, de momento, por un bote en que leu The Body Shop, e a continuación Against animal testing. Os dedos da muller danzaron e tentearon pola zona máis finalmente repararon nas pinzas de depilar. E puido Don Xil domear a parte do medo que andaba polos ollos, pois o tempo non pasaba ou ía moi de vagar polas canas das cellas da que estaba no espello. Nos adentros, tanto como o efecto da súbita claridade, tremíalle a memoria recente da súa sobriña espida, o corpo tenuemente iluminado pola luz das brasas, aquel xeito de bañar a pel como vidreira atravesada polo solpor do lume, e, sobre todo, a revelación daquel corpo que era na vellez lirio, tan mórbido e duro a un tempo semellaba, que esta é a maneira misteriosa que ás veces pousa o tempo. (Rivas 2008a: 37)

O primeiro parágrafo constitúe unha fermosísima descrición erótica: espirse diante do braseiro, agarimosas linguas de calor, hedras ardorosas que gabean e bican os seos, seos como loto ou camelia... Aínda non sendo obxecto do noso estudo non podemos deixar de destacar as sensacións táctiles tan poderosas que emprega o autor: "sentía como intenso ese pracer agora, o lambido frío do lobo da noite polas costas, as agarimosas linguas da calor que engatan por diante". Sucede que a visión da muller non lle corresponde ao autor omnisciente (que está presente pois tamén conta o feito da ollada) senón a don Xil de Arán, convertido, ao estilo de Hitchcock, en rato voyeurista, que non puido reparar nun pormenor (se o pixama era de home ou de muller). A descrición semellaría un movemento panorámico horizontal de pés a cabeza (pés fríos, coxas cinguidas, seos bicados, guedellas enredadas) pero o segundo parágrafo, despois do estalido de luz, imita o movemento da cámara ao ombreiro, xustificado pola cegueira luminosa e pola irrupción, nas proximidades, da muller contemplada. Don Xil observa, sen orde ningunha, o esmerilado da beira do espello, a muller da caixa de cartón, os botes de xel de baño, e as cellas da muller no espello. Mesmo o "efecto da súbita claridade" que volve ao rato a imaxe anterior, "a memoria recente da súa sobriña espida", pode interpretarse como un pequeno inciso de montaxe, un micro flashback, como cando nas películas se repite unha imaxe que obsesiona ou estimula un personaxe $\mathrm{e}^{22}$.

22 Pensemos, por exemplo, nas breves lembranzas do seu secuestro cando neno que o adulto Dave Boyle (Tim Robbins) ten en Mistic River (Clint Eastwood, 2003). 
O zoom consiste nun cambio da distancia focal, co que tamén cambia o encadre. Xa con anterioridade (no apartado relativo ao travelling) analizabamos como o narrador (o barco personalizado) narraba o movemento dos pasaxeiros desembarcados. Descrición que semella ao dun zoom pois ao afastarse do barco os pasaxeiros só podemos manter a distancia mediante un dispositivo que nola achegue:

Cada atraco no desembarcadoiro de pedra, a muller e o neno baixan de primeiros e andan máis aló da rampla lousada por diante da fileira das policromadas casetas de baño. O home camiña a distancia. Leva a chaqueta dobrada no brazo, e a camisa branca, de manga curta, desabotoada no peito, devólvelle realidade ao seu corpo. Hai un quiosco de madeiras con refrescos e xeados. Alí alugan as casetas e a muller paga, toma a chave e volve sobre os seus pasos. (Rivas 2006: 537-538)

Acaso o cinema non sexa senón, como expresaba o xenial director de fotografía Sven Nykvist no seu libro, un culto á luz, un tributo á luz, case unha eucaristía luminosa. Se observamos por exemplo, a secuencia de Citizen Kane na que o xornalista Jerry Thompson (William Alland), vai ler as memorias de Mr. Thatcher observamos unha luz oblicua, como de ultratumba, unha lembranza de que o que estamos a ver son as reflexións dun home xa no outro mundo. A luz non é unicamente unha necesidade para ver, adquire valores simbólicos, valores que tamén atoparemos na literatura. Tamén na obra de Rivas se dá este uso simbólico da luz:

De entre as altas sebes de loureiro saíu a lúa cun relampo de fachendosa alquimia. No desconcerto da repentina claridade, o rufián deu un paso en falso e tronzou cun pé unha póla seca que acabou por esnaquizar a densidade do medo. Marisa sentiuse liberada do aire do lobo e, con coraxe, correu a mirar por enriba do ribazo. No costeno, recortábase, fuxidía, a silueta en sotana do pater confesor. (Rivas 2011: 336)

A claridade liberadora alíase coa moza acosada e evita a súa inminente violación da muller, ao tempo, á escuridade, era a aliada do lobo. A luz perde o seu carácter de elemento natural e causal e adquire un valor transcendente, mesmo un papel protagonista.
O segundo domingo de xullo viñera cun dispendio de luz. Ninguén se podía fiar dese ceo de vertixe, a porta de todas as borrascas dos Azores, nin sequera en pleno verán. Máis desta vez atinaran na misión. [...] Polca pensou que verdadeiramente o segundo domingo de xullo era un agasallo que merecía unha bendizón. (Rivas 2006: 35)

Rivas utiliza de xeito moi elegante este recurso; a descrición dun día soleado normalmente asociado a nunha época tranquila e gozosa, entra en contradición co "dispendio de luz", un exceso; a luz preséntase como pouco fiable pois ese "ceo de vertixe" anuncia os temporais, e non só as tormentas de estío senón a inminencia do comezo da Guerra Civil, xa que estamos no segundo domingo de xullo de 1936.

Compartimos con Patricia Antón (2007: 249) que a presenza da imaxe dentro da imaxe é un "guiño metavisual", un trazo cinematográfico presente na literatura. Non obstante, non podemos deixar de comentar que a presenza dos espellos e dos retratos nos textos literarios ten unha longa tradición. Pensemos no escudo de Perseo consegue evitar a ollada mortal de Medusa, na madrasta de Brancasneves interrogando sobre a beleza das mulleres da corte, nos espellos de Cunqueiro que mostran demos colgados dunha pereira, cabalos galopando sobre o mar ou camiños despois da néboa. Ás veces os espellos chegan mesmo a se converter no modelo da creación literaria, pensemos en Stendhal querendo converter á novela nun reflexo mimético do camiño ou en Valle-Inclán creando o esperpento ao xeito das imaxes cóncavas e convexas que se reflectían na canella do Gato; noutras ocasións, como labirintos enciclopédicos, son un instrumento para coñecer a realidade como en "Tlön, Uqbar, Orbis Tertius", o conto de Borges. E, en ocasións, as imaxes, como no retrato de Dorian Gray, acaban por ter a vida que os personaxes renuncian a ter. Claro está que os espellos non atrapan o máis alá, por iso os vampiros non se reflicten nel ${ }^{23}$.

Debemos considerar "espello" calquera superficie "capaz de visualizar a quien mira, en consecuencia de convertir a un personaje que observa en observador de sí mismo" (Antón 2007: 249) e non só un moble elaborado

23 Un curioso exemplo atopámolo na versión que Manuel Palacios realizou do relato de Manuel Rivas “A rosa de pedra". Nel, o cego Bastián, encarnación do espírito do Camiño de Santiago tampouco pode ser captado pola cámara fotográfica de Mireia malia estalo a observar polo visor, pois é un ser doutro mundo. 
fundamentalmente con vidro, pois a función especular, na obra de Rivas vai ser desenvolvida, como imos ver, por distintos obxectos. Un dos momentos máis espectaculares da obra de Rivas, no sentido de converter a literatura en espectáculo, atopámolo no seguinte parágrafo:

Había un cuarto especial. Un cuarto cheo de espellos. O mesmo teito era de espello. A señora que a guiaba, a que vivía alí e que era unha figura estraña, non sabía se hóspede ou gobernanta, explicoulle polo baixiño, como se non quixera que oíran as imaxes dos espellos, que esa era a suite que utilizaba o señor Manlle para desfacer a cama coas súas amiguiñas. Desfacer a cama. Amiguiña. Fíxolle graza a maneira de dicilo. Ó xirou sobre si mesma e multiplicouse a súa imaxe polas paredes. (Rivas 2006: 586)

O texto está empapado de referencias cinematográficas, non só pola homenaxe clara a The lady from Shanghai (Orson Welles, 1947), senón polo feito de que, ao ser o local das aventuras sexuais do Manlle remite ao cine como arte de miróns preconizado por Hitchcock. Ademais a gobernanta ou hóspede era unha figura estraña, expresión ambigua que pode referirse ao cometido da muller ou a súa propia fisionomía. Fixémonos no xogo, case borgeano, entre espello e realidade pois a gobernanta fala baixo "como se non quixera que oíran as imaxes", daquela as imaxes teñen unha entidade maior cá de ser simples reflexos. Ó, Olinda, ao xirar sobre si mesma, e, polo tanto ao cambiar a posición e, sobre todo, a perspectiva, multiplícase polas paredes.

Reparemos noutro exemplo no que os espellos son moito máis cá un lugar no que mirarse:

Sen deixar de contemplarse, devolta a imaxe co sorriso melancólico que os espellos reservan en familia, abriu Misia o caixón da coqueta e trouxeron as mans unha alfaia que ao abrazarse ao pescozo viuse que eran follas de acivro con bagas de acibeche engastadas á antiga maneira. E aí foi que Don Xil viu todas as donas que andaron os corredores do pazo ou pasaban languidamente as horas na solaina, entre begonias e xeranios, mentres chovía sobre a pel do mundo. E ao transfigurado púxoselle un nó na gorxa porque todo o que se viñera abaixo resplandecía, victoriosa sobre as ruínas, finalmente recoñecida polo espello. (Rivas 2008a: 38)
Notemos que os espellos teñen iniciativa, reservan en familia o sorriso melancólico e, máis alá das ruínas, teñen a capacidade de reflectir o esplendor pasado.

Outra superficie que pode reflectir unha imaxe é o vaso: "O mundo estaba na peceira do vaso, deformado polo grande angular. Puido ver a figura dela no fondo. Achatada, silenciosa como unha india das películas. Tomou un grolo longo. (Ibid. 186). Reparemos de novo na pátina cinematográfica de Rivas, non só pola presenza da imaxe dentro da imaxe, senón tamén na mención da india das películas para explicar a posición de Rosa e da tecnoloxía do grande angular para explicarnos a natureza da imaxe reflectida. Non esquezamos que a imaxe deformada remite á estética valleinclanesca ${ }^{24}$.

Tamén a auga pode reflectir unha imaxe:

Unsoldadocon cara deneno emirada dehome. Un soldado lampo. Unha guerreira de botóns grandes e de colo duro. Enmarcado nun circo de auga. Ten os brazos cruzados e na manga do esquerdo vese un distintivo. A mirada de home, si. Non me mira fachendoso, mais tampouco con mágoa. É o que teñen as figuras da auga, que veñen ver, que miran cando as miras. (Rivas 2006: 14)

Outro vez un texto anegado de cine. A sinalización do encadre, "enmarcado nun circo", remite ás trucaxes do cinema. Por exemplo en Das cabinet des Dr. Caligari (Richard Wiene, 1920) os personaxes aparecen frecuentemente enmarcados nun círculo. O salientable, o orixinal deste texto, non está en que un ser se observe a si mesmo, senón que dous seres se observan a través dunha imaxe e que a protagonista toma consciencia do tipo de ollada a través do reflexo da mesma. Vexamos o contraplano narrado un pouco máis adiante na novela:

Mentres ela enxaboa, eu miro de esguello, primeiro cara á súa imaxe na auga e logo para ela. Está a contraluz, leva o pelo recollido nun pano anoado na caluga, e agora volve ter o ricto da dureza. É dura cara a dentro. Os seus ollos gardan. Iso vese mellor na auga. (Rivas 2006: 17)

Esta contraollada do mozo, esa mirada a contraluz -elemento lumínico- permite unha contemplación que describe a imaxe que ve primeiro no reflexo e logo na realidade pero insiste 
en que a verdade da ollada ("os ollos gardan") está no reflectido, "vese mellor na auga".

Finalmente os propios ollos poden permitir a contemplación dunha imaxe: "Houbo un momento, dous metros da besta, en que o home entendeu que era el o que estaba a proba: xusto cando se viu reflectido no puro acibeche dos ollos do animal. (Rivas 2008a: 62)". O reflexo ocular mostra non unicamente unha figura senón tamén unha situación anímica: sentirse "a proba".

Os retratos, di Patricia Antón, serven para poder desdobrar o personaxe noutro elemento de similares características (2007: 249), e permítennos pois, en ocasións, establecer unha comparación co personaxe que se sitúa fronte a eles (Ibid. 253). A creación da imaxe dun retrato e a súa contemplación nunca son simultáneas polo que, este mesmo paso do tempo, permite establecer similitudes e diferenzas entre os dous instantes: o presente e o pasado ou varios pasados, como podemos ver no seguinte exemplo do autor de Monte Alto:

Hai unha foto de familia no álbum. Unha foto oficial, por dicilo así. Foi feita nun estudo de fotógrafo, en Catro Camiños, na Coruña. Estamos os seis, meus pais cos seus catro fillos, as dúas mulleres e os dous varóns. Todos estamos moi serios. Neles, nos pais, hai unha expresión de certa desconfianza. A cámara, sobre todo se se sente interpelada, rexistra moi ben ese sentimento. Aínda hoxe está alí, na foto, unha vibración de impaciente hostilidade. Poderiamos estar xuntos nunha foto, claro, e mesmo contentos de estarmos xuntos. Algunha así hai, nalgunha festa, e tempo despois. Se estamos alí, no estudio fotográfico, é por obriga, por necesidade. Por optar ás bolsas de estudo universitario, que estabamos a tramitar María e mais eu, pedíannos adxunta unha foto de "familia numerosa". Lembro ben o día. Chovía. Meu pai fixera unha escapada do traballo e tiña présa. Alisou coas mans o cabelo humedecido, cara atrás. Era xa un urdido de tempo, en branco e negro. (Rivas 2012: 141)

A imaxe en branco e negro por si mesma evoca un tempo pasado. O estilo da fotografía, o dun documento oficial, sitúanos no ámbito das obrigas e explica así a incomodidade e a contrariedade por parte dos retratados, en contraste coa espontaneidade familiar: "poderiamos estar xuntos nunha foto, claro, e mesmo contentos de estarmos xuntos". Deste xeito a imaxe mostra unha época e unhas relacións de familia nas obrigas burocráticas e na intimidade.
Tenta apartar a saba de papel, mais agora é a folla do xornal a que non quere soltarse. Trata de envolvelo. [...]

Vén aquí, dille ao papel. Para quedo. Co grande que é o mundo, non tiñas outro sitio onde ir?

Unha foto. Chámalle a atención porque é a única foto e o escenario moi real. Semella tomada dende o lugar onde el mesmo está. E o que se ve no fondo da foto do xornal é tamén o que el pode ver. As fogueiras. Os libros a arder, mais tamén as falanxes que os queiman, a facer o saúdo fascista. Agora entende o porqué a folla se abrazou a el, Vén fuxindo das lapas. (Rivas 2006: 156)

De novo estamos diante desa función comparativa, antes comentada; o protagonista pode ver como a imaxe que contempla e quere retratar semella á reflectida no xornal, pode contrastar punto por punto o que ve: os libros e as falanxes, pois teñen a mesma posición. Ademais a foto anda na súa procura, como querendo obrigalo a observar. A imaxe, por outra banda, fuxe das lapas, do esquecemento, e abraza, apégase, cínguese, ao protagonista na procura dunha ollada e de manterse na memoria.

Se con anterioridade comentabamos superficies diferentes do vidro capaces de reflectir unha imaxe, agora temos que dar conta doutras nas que se pode imprimir un retrato. Reparemos en primeiro lugar na caixa.

Tiña na tapa a imaxe dunha moza cunha froita na man, cun pente no cabelo, cun vestido vermello estampado de flores brancas e volantes nas mangas. A primeira vez que viu a Marisa Mallo foi como se saíse da caixa de marmelo para pasear pola feira grande de Fronteira. (Rivas 2005a: 45-46)

No texto a anónima e atractiva muller do recipiente encárnase en Marisa Mallo a fermosa veciña pola que Herbal se sentirá atraído toda a súa vida. A imaxe serve, unha vez máis, para contrastar, para comparar uns personaxes cos outros.

No cinema, a televisión pode aparecer como un electrodoméstico máis da casa, ás veces, o director aproveita a presenza deste obxecto para render homenaxe a un autor admirado, pensemos na escena de E.T.: The Extra-Terrestial (Steven Spielberg, 1982) na que o visitante espacial contempla The quiet man (John Ford, 1952). En Husbands and Wives (Woody Allen, 1992), na televisión aparece un experto a falar do universo e conclúe coa frase de Einstein segundo o cal: "Deus non xoga aos 
dados co universo" o que permite que o personaxe interpretado por Allen conclúa que: "xoga ás escondidas". De modo que a realidade da televisión interactúa co personaxe da ficción cinematográfica, rompendo así a unidade de espazo. Esa mesma quebra podemos observala no seguinte parágrafo:

$\mathrm{O}$ locutor anunciou que se cumpría o tempo. $\mathrm{O}$ árbitro consultaba o reloxo. Logo, na pantalla viuse a bancada local e a cámara enfocou o rostro apesarado do míster. O home de pelo cano tivo a rara sensación de estar diante dun espello. Afundiu a cabeza entre as mans e o adestrador imitouno. (Rivas 2011: 152)

A acción transcorre no fogar do espectador pero tamén no estadio de Riazor. Hai unha ruptura da unidade de acción pois a conversa familiar transcorre paralela ao partido de fútbol. Pero, nun aparente paradoxo, esta disgregación remata por provocar unha fusión entre a imaxe do personaxe televisivo e o real. $\mathrm{O}$ pai pescador e o adestrador do Deportivo da Coruña, Arsenio Iglesias, acaban por identificarse, non só porque ambos sexan homes de pelo cano senón porque o adestrador realiza os mesmos xestos. Esta conexión maniféstase dun xeito moi elegante pois a imaxe imita a realidade de xeito case simultáneo, recalcando así na unión de ambos personaxes.

Tamén podemos atoparnos coa imaxe do cinematógrafo. As funcións serían moi semellantes ás da televisión. Vexamos como algúns personaxes interactúan coas películas:

Pero a primeira vez que oín chorar, chorar de verdade, a primeira vez que dixen isto é chorar foi cando Charo A'Rubia no cine Rex. Botaban Capitáns intrépidos, unha película na que traballaba Spencer Tracy [...] Moito me gustaba a min cando inventaba a luz. Ben, pois na película Capitáns intrépidos o Spencer Tracy facía de pescador en Terranova. [...] O pescador Manuel tocaba unha zanfona e cantáballe ao neno rico cun agarimo que nos daba envexa.

Ay, mi pescadito, deja de llorar!

Ay, mi pescadito, no llores ya más!

E foi entón cando chorou Charo A'Rubia.

Era o seu ao principio un chorar mainiño que se confundía co zunido morriñento da zanfona. Decateime porque ela estaba moi preto, xusto ao me carón, dixo Antonio Ventura. Colleu un pano branco e tratou de conterse tapando os ollos. Pero o pranto ía a máis, até que os saloucos desbordados ocuparon todo o cine como se saísen da mesma pantalla. [...] Choraba Charo A'Rubia e até pareceu que o Spencer Tracy deixaba a zanfona para mirar con mágoa saudosa cara ao patio de butacas. Recordo estarrecido aquel pranto, o mar de bágoas caendo sen consolo, salpicando o meu abriguiño cheviot.

O home de Charo A'Rubia morrera había dous anos en Terranova. (Rivas 2011: 238-240)

A interrelación entre a pantalla e o acontecido no local non precisa explicación, a empatía entre Charo e os personaxes tampouco. Se cadra cómpre destacar como o autor, insiste nesa relación coa expresión "mar de bágoas" que inevitablemente se asimila ao mar de Terranova onde pescan os personaxes do filme.

\subsection{As características auditivas}

O terceiro tipo de influencias cinematográficas na literatura son as de carácter auditivo. No principio foi o silencio, a tecnoloxía non permitía sincronizar unha imaxe cun son polo que os espectadores contemplaban só as primeiras. Coa chegada do son, defende Fernando Trueba: "el cine descubrirá dos de sus armas más poderosas: la palabra y el silencio. Por no hablar de los ruidos, en los que incluimos la música" (2006: 225). Para a literatura a palabra non constitúe un descubrimento, é a esencia mesma, o seu ser, o elemento sen o cal nada sería. Con todo, existen algunhas formas de manexar as palabras que son propias do cinema. Luis Goytisolo (1995: 25) sostiña que na literatura contemporánea atopamos diálogos de carácter enunciativo e coloquial que teñen a súa orixe na sétima arte. Os acoutamentos teñen un carácter "objetivista, neutro y sintético, que funcionan a modo de acotaciones escénicas" (Antón 2007: 245) e suxiren o plano contra plano. Nas conversas que transcribimos a continuación podemos observar estas características.

-Ei, tío! -dixo Tip-. Que fas aquí, tío?

-A perna! -dixen eu, mostrando as muletas o máis triunfante que puiden-. A perna, he, vaime quedar máis curta cá outra, he, he.

-Iso é estupendo! -dixo Tip.

-Que demasiado! -dixo Top.

O corazón dábame saltos de alegría. Se alí estaban Tip e Top, non podía estar lonxe Don. E onde está Don sempre hai Algo para os amigos.

-Don está aquí, sabes? -dixo Tip, moi polo baixiño, cunha guillada cómplice.

-Si, está aquí -dixo Top un pouco máis alto. 
-Está aquí Don? -dixen sen poder disimular, tanta felicidade.

-Operárono de apendicite! -dixo Tip como se fose un extraordinario acontecemento.

-Si, de apendicite, ha, ha -dixo Top.

-Apendicite? Ha, ha -rin eu tamén. Nunca souben moi ben que era iso, pero era algo do que se operaba a xente e que debía ser moi gracioso. (Rivas 2008c: 37-38)

O rexistro coloquial é claro, non só porque os mozos e empreguen expresións como "tío" ou "demasiado", senón pola velocidade das respostas. Non hai tampouco grandes indicacións por parte do narrador á hora de mostrar as intencións ou xestos superfluos senón que se centra na transcrición do diálogo.

-Págoche para que me digas cando fago o parvo e non para que pases o día dándome palmadiñas -dixo o candidato.

-Non sabía que lle tiveses medo aos ollos dos peixes -respondeu o asesor.

-Non me dan medo. Simplemente, non os soporto.

-Viraches a cara. Nada máis. Non creo que isto nos reste votos.

-Pero a muller deuse conta. Cando lle dei a man, miroume con receo, coma quen descobre un segredo indesexado.

-Son aprehensións de fin de campaña. Estás canso. Iso é todo.

-Non sei como fun capaz de darlle a man. Limpouna no mandil. Pero aínda tiña escamas.

-Era unha peixeira, unha pescantina bigotuda. Nada máis.

-Fíxose un silencio longuísimo. Como o dunha fotografía. (Rivas 2011: 49)

Neste parágrafo procedente do relato "Unha visita ao mercado" só se nos dá a referencia dos personaxes en cadansúa primeira intervención e ningunha outra indicación, como se o lector os ollase e non precisase máis explicación.

En ocasións os diálogos forman parte da narración, insírense nela formando un todo, prescindindo incluso dos puntos e aparte ${ }^{25}$ :

¡Esperta, os ferrollos!, alertou o pintor, sacudindo a Herbal da orella. Non, non esta vez non, díxolle o garda á voz. Acabouse. Déixame en paz. Se ten que morrer, que morra dun raio dunha vez. Escoita. ¿Vaste botar agora atrás?. Ti non corres ningún risco dixo o pintor. ¿Que non? respondeu Herbal a piques de berrar. Voume volver tolo, ¿paréceche pouco? Non está mal para estes tempos, dixo o pintor lacónico. (Rivas 2005a: 55)

Non podemos rematar esta apartado sen dedicar unhas liñas a falar das palabras de cine, de como estas se converten en patrimonio comunicativo. No seu traballo "Lo que el cine nos dejó: la herencia fraseológica", Ricard Morant e Debra Westall analizan a influencia do cinema na nosa vida lingüística. Segundo estes autores tres son as causas que a motivan, a primeira o moito tempo que lle dedicamos, a segunda a facilidade con que conectamos con ela, e a terceira a fascinación que producen.

Se nos paramos a considerar os comportamentos sociais dos últimos anos, atopamos que moitas modas proceden da sétima arte. Os citados Morant e Westall sinalan, entre outras, algunhas prendas de vestir como os vaqueiros, as bermudas, os bikinis ou a rebeca; algúns xestos como o costume de protestar unha decisión arbitral erguendo as mans ou certos usos das musicas como por exemplo determinados tons dos teléfonos móbiles ou o uso da música da carga do sétimo de cabalaría (Ta tari, tari, tari, ta, ti to ti ti to ti!) para narración, por parte dalgúns locutores, dun contraataque nun partido de fútbol. etc.

Pero ademais o cine deixa pegadas na linguaxe común. Os autores citados mencionan, entre outros, o uso de determinados acentos para caracterizar determinadas etnias ou nacións, por exemplo ou uso abundante de "aes" para imitar un suposto acento dos negros ou a substitución do $<\mathrm{r}>$ polo $<\mathrm{g}>$ para identificar a fala dos franceses. Tamén na formación de palabras se pode detectar este fenómeno. $\mathrm{O}$ abuso do prefixo super (superdivertido, supermegaguai...) ou o sufixo "-oide", tan frecuente na saga de $A$ Guerra das Galaxias que mesmo chega a influír en nomes propios como "Os Pegamoides". Tamén sinalan que algunhas palabras como "linchar" ou "cartucheras" acaban tendo unha significación diferente da orixinal. Mais se hai un campo onde a invasión de cinema é enorme, este non é outro que o

25 Poida que o autor non usa estes signos de puntuación porque o diálogo ten lugar na mente dunha persoa. 
dos insultos: ser "un Rambo", un "Parque Xurásico" son dabondo elocuentes, como o son os diminutivos "dumbín" ou "draculín”, ou a infinidade de expresión que indican a fealdade de alguén (aí van "a bela e a besta", "Tarzán e a mona chita", etc.).

Se cadra, o traballo de Morant e Westall incide no negativo do uso do vocabulario procedente do cinema, porén en Rivas atopamos exemplos de todo o contrario, por máis que tamén empreguen "Rambo" como insulto, un personaxe pode ter "un sorriso Mastroianni" ou unha ollada "tipo Robinson"...

Sorprende que malia que, no título do artigo se mencione a herdanza fraseolóxica, os autores non afondaran máis neste interesantísimo aspecto, probablemente por razóns de espazo. Chamaremos unidades fraseolóxicas (UU.FF). "aquelas combinacións de palabras que se caracterizan pola alta frecuencia de aparición na lingua e están formadas por dúas ou máis palabras e cuxo límite superior é a oración" (Ángelova Nénkova e González-Espresati 2008: 16). As UU.FF. caracterízanse pola súa idiomaticidade, é dicir, porque o seu significado non se deduce necesariamente da suma dos sentidos de cada un dos seus compoñentes; por estaren institucionalizadas, isto é, por seren adoptadas pola comunidade lingüística, e seren fixas, polo que os falantes as reproducen en bloque, coma unha unidade.

Son moitas as clasificacións das UU.FF., se cadra a máis estendida sexa a que as divide en: colocacións, locucións -pensemos en "é de película" ou "é de cine"- e enunciados fraseolóxicos. Dentro destes últimos hai que incluír proverbios, wellerismos e citas. Será precisamente, neste apartado onde o cine está a deixar unha copiosa herdanza. Frases como "sempre nos quedará París"; "Houston, temos un problema", forman parte da frases comúns da lingua. Rivas tamén emprega con profusión as citas, como veremos no apartado dedicado á intertextualidade.

Cando me atopo con algúns deses tipos cínicos, da escola da inquisición, prefiro remitilos a unha película do Oeste, alí cando James Stewart lle di a un badulaque que dispara polas costas: "Se cho teño que explicar, non serve de nada". (Rivas 2008b: 262)

O pai, e mais se é escritor, debería adoptar a dignidade distante de Humphrey Bogart, cando se negaba a ser maqueado antes de filmar: "Non me tapedes as enrugas que me custaron moito traballo". (Rivas 1999: 292)

Son palabras de cine, loabámoste luz, palabras que como citas ou como locucións chegan para quedarse e enriquecer o noso patrimonio expresivo.

Seguramente non sería unha aberración afirmar que algunhas das mellores pezas musicais dos últimos 120 anos se compuxeron para o cine. A música na sétima arte foi adquirindo maior complexidade a medida que a arte cinematográfica evolucionaba. De mera acompañante das imaxes, chegou a dar forma a un xénero propio: o musical. Un xénero co que se inaugurará o cine sonoro ${ }^{26}$ e que producirá obras mestras indiscutibles como Cantando baixo choiva (Standley Donen, 1952), West side Story (Jerome Robbins e Robert Wise, 1961). A música ten a misión de acompañar o ritmo ${ }^{27}$ das imaxes ou de subliñar os sentimentos ou as ideas que queren destacar.

Ás veces a literatura válese da música, da mención da música, mesmo da música do cinema, para expresar un ritmo. Así, por exemplo, o personaxe principal de Os comedores de patacas recupérase no hospital ao compás da música de Per qualque dollaro in più (Sergio Leone, 1965), composta por Ennio Morricone: "Colléralle gusto a A morte tiña un prezo. Axudábame a andar" (Rivas 2008c: 37). O mozo protagonista desta novela enfádase co seu irmán porque lle trae unha cinta de música allea ás súas preferencias. Sucede que, vaise afacendo a elas e que, en concreto a música do filme de Leone, vai ser a que marque o ritmo da súa recuperación: "axudáballe a andar".

Reparemos nun novo exemplo:

Espertei co son da gaita e dunha canción que me baixou polo espiñazo como lapa polo túnel dun formigueiro.

O cantor de jazz (Alan Crosland, 1927) foi a primeira película con son sincronizado.

27 Moitos estudosos (cf. a carta ao director de Carmelo Núñez Sanz “Eyes Wide Shut” publicada en El País 01/10/1999) consideran que Stanley Kubrick rodaba as súas películas ao ritmo dunha banda sonora previamente elixida, empregando en cada caso un compositor determinado: Beethoven, Mozart, Strauss...; incluso hai quen cre ver unha asociación entre a música e algúns eixos temáticos así, Beethoven en A clockwork orange (1971) sería a liberdade ou Mozart en Eyes wide shut (1999), a morte. 
Non hai nada, pai,

como o doce colo da nai.

Todo foi a pique,

todo o gastei,

bailando na casa

de Mary Stand By. (Rivas 2008e: 60)

Bala perdida cantaruxouna levando o ritmo coa pata de madeira. Soaba como un pau nun tambor.

Tres pasos adiante.

Tac tac tac.

Tres pasos atrás.

Tac tac tac.

Viras á dereita

e alí están.

A miña ruína,

os ollos de azucre

de Mary Stand By! (Ibid. 61)

A reprodución dunha canción provoca unha emoción na moza protagonista desta novela de aventuras. A melodía prolongarase ao largo da obra, como se dun tema principal se tratase, e ademais vai ser clave na identificación da personalidade, no proceso de anagnórese, do seu intérprete. No momento do recoñecemento a moza protagonista exclamará: "Santo ceo, eran eles, a nosa canción!” (Rivas Ibid. 104).

Outras veces a banda sonora consiste na recreación dos sons da natureza ou dos sentimentos:

A clínica O Salgueiro Tranquilo estaba situada nun fermoso lugar, no alto dun outeiro desde o que se dominaba Atlán, a grande cidade portuaria que antano fora un pequeno e bravo niño de pescadores. O da nosa liberación era un día sollío, xaspeaba a paisaxe de moitos matices de verde e azul. Tocaba o himno unha orquestra de xílgaros, merlos, chascas e paporrubios. (Ibid. 111)

A liberación da protagonista vai acompañada dun fermoso día de sol, e coa música dos xílgaros e merlos como se o estivesen a celebrar. Xílgaros e merlos que non se oían durante o tempo de presidio.

Outro dos aspectos sonoros salientables do cine son os ruídos. Moitas veces limítanse a acompañar a acción ou a remarcar a situación, outras teñen un valor estético maior. En Rouge (Kristof Kiezlowski, 1994), por exemplo, o desenganado namorado diríxese á cafetería onde sabe que se reúnen a súa amada e o seu novo amante e cun bolígrafo chama na cristaleira. A intensidade emocional vese reforzada, precisamente, pola ausencia de calquera outra referencia sonora (non oímos a conversa dos namorados, nin música de fondo), só o bater no cristal. Estes efectos de son, por estraño que pareza, tamén os podemos atopar na literatura de Rivas.

Os ratos non paran de bulir no faiado e no ceo. Patiñas de ratos que corrican no teito. Enormes ratos que pilotan cazabombardeiros entre as nubes. Ratos que roen a miña cabeza. Ollos brillantes de ratos que escintilan nos vidros, entre as macetas de xeranios. Nico roncando coma un rato xigante, farto de millo, entre as sabas. Onde haberá Algo para durmir? Sei que a avoa garda nun chineiro as cousas de tomar. Ten que haber algo parecido a Algo. En todas as casas hai algo así. Baixo amodiño as escaleiras do sobrado, e os lóstregos prenden nos pés espidos. Embaixo, as brasas da lareira tamén parecen asustadas nunha esquina. (Rivas 2008c: 77)

Os sons dos ratos no faiado non deixan de ser unha metáfora do síndrome de abstinencia do rapaz. Na noite, no desexo de droga (Algo) sente ese bulir físico dos roedores pero tamén o bulir das súas células.

Ás veces, as palabras constitúen tamén un ruído de fondo e non un verdadeiro diálogo:

Aquela noite papá rezou canda nós e os murmurios do rosario foron para min por vez primeira palabras que se oían e entendían. Sentíaas como puntadas, como agullas de bordar a atravesar a pel. Papá sacoume de aquí en canto puido, levoume case sen despedirse como fuxindo dunha maldición, como se temese que alguén accionara nas pedras unha trampa oculta que me engulira. (Rivas 2008a: 49)

O murmurio do rosario, por máis que, por primeira vez, entenda o sentido das súas palabras, non deixa de ser un acompañamento, o son do lamento pola marcha, o soar inconfundible do desacougo.

\subsection{As relacións intertextuais}

O cuarto tipo de influencias do cinema na literatura son as relacións intertextuais. Toda vez que o concepto de intertextualidade é complexo e polisémico, convén aclarar neste momento que seguiremos a definición de Beaugrande e Dressler quen a definen como o conxunto de "factores que hacen depender la utilización adecuada de un texto del conocimiento que se tenga de otros textos anteriores" (1997: 45). Xa apuntaramos que as referencias ao cinema en Manuel Rivas son tan abundantes, 
tan constantes que poderíamos consideralas un verdadeiro decorado. O campo semántico do cine emerxe aquí e alá como variacións dunha banda sonora. Constatamos máis de cento cincuenta filmes citados ${ }^{28}$ : "Dicir coa solemnidade e a coraxe de Johnny Guitar: dime que me agardas, que me queres aínda que non sexa certo etcétera, etcétera" (2010a: 35); máis de setenta e cinco directores: "O tren galego vai camiño de ser un recordo romántico polos outeiros neboentos, coma un fotograma de John Ford" (1999: 178); máis de setenta actores: "Baixo a chuvia de pedras, vexo a Luís Pita sorrir coa súa gabardina existencialista que xa foi de Bogart e de Camus" (Ibid. 287); un nutrido grupo de personaxes, tanto personaxes tipo: taberneiro, moza do salón, sarxento: "En Vida de can, en 1918, o revolucionario Chaplin atreveuse a contar as vidas paralelas do vagabundo, a moza do salón e un can de palleiro" (2008b: 15); como personaxes individualizados: Guido, Charlot, Tarzán, Viena...: "Quizais os mau-mau falaban, cando saían do seu territorio, a lingua de Tarzán" (2006: 271) $)^{29}$.

Pero a intimidade do autor de Monte Alto co cinema percíbese mellor en que tamén ten un lugar para os oficios con menos glamour como os guionistas: "Foi o premio en Venecia, o que espertou a atención cara ao extraordinario filme con guión de Azcona" (Rivas 2008b: 166); o director de fotografía: "En eso se nota que Trenas es un buen director de fotografía. Porque no solo habla bien de la gente, sino también de las cámaras, que son muy sensibles" (2013: 172); os extras: "Cheo de extras saídos dos momentos menos chistosos das películas de Charlot que eu ía ver no cinematógrafo do Kiosko Alfonso, moi preto de alí" (2008a: 56); o pertiguista: "Ahora veo al pertiguista. Ese cuerpo hercúleo que sostiene el escucha" (2013: 179), etc.

Máis alá das persoas participantes emerxe o vocabulario da tecnoloxía (cámara, fotograma, moviola...): "E deixáballes levar os anacos de celuloide que el cortaba para empalmar a película cando rompía" (Rivas 2010b: 6830); e da técnica cinematográficas (travelling, panorámica, western, etc.): "Agora, no travelling da cinta mecánica, Mireia notou que unha adicción de gris despexaba o gris afumado" (2011: 246).

$\mathrm{O}$ autor coruñés tece un verdadeiro tapiz, un tapiz cosido coa finura da montaxe e a variedade cromática do tecnicolor.

As citas cinéfilas non son unha demostración estéril de erudición, nin soamente unha oportunidade para que o autor comparta as súas predileccións estéticas: "Julie, Camielle, $\mathrm{Ada}^{31}$... Algo tiene que estar pasando en la sensibilidad del mundo para que surjan tres personajes así en la ficción del cine" (Rivas 1997: 320). As referencias á sétima arte acompañan ás preocupacións máis salientables do autor, como poden ser a defensa do medio ambiente, a memoria histórica, a defensa do galego e mesmo o sentido da existencia.

Máis o xénero que pode recompoñer a trama enteira do caso Prestige, coser os farrapos da historia, os anacos de filme nunha montaxe con sentido, é, sen dúbida o que dá en chamar novela negra, ou policial ou thriller, en xeral. (Rivas 2008b: 260)

Hai quen di que desculpas hai para todo e solta o refrán: ¡Deus che perdoe, se atopa por onde! Está claro que Franco era un mal bicho que desaparecerá polo sumidoiro da historia. Quen queira poñerlle un altarciño que o faga na súa casa, a carón do televisor e da ristra de allos, aínda que sería mellor que puxera un póster de Sharon Stone. (Rivas 1999: 283)

Causáballes hilaridade que Bogart ou Xerónimo falasen galego nas películas, como se Humphrey e o xefe indio fosen castelán falantes de toda a vida. (Rivas 1999: 223)

El cine reinventa la realidad, pero la realidad, allí donde se ventila la vida, también tiene una voluntad cinematográfica. (Rivas 2013: 176)

Como quedou dito, cando a beleza do mundo parece elevarse, parece transcender, cando este se manifesta en plenitude, semella necesitar do cine para ser descrita:

28 A partir deste momento e, por razóns de espazo, só achegaremos unha ou dúas citas por elemento.

29 Gabriel, un dos personaxes da novela, falaba unha lingua secreta e comparábase cos Mau-Mau, unha tribo que no tempo da novela era coñecida polo seu carácter rebelde.

30 A novela Todo é silencio está chea de referencias a películas, especialmente a O padriño (Coppola, 1972) e $A$ fiestra indiscreta (Hitchcock, 1954). Aquí vese a homenaxe a Cinema Paradiso (Tornatore, 1988).

31 Refírese ás protagonistas de Azul (Krzysztof Kieslowski, 1993), Un corazón en inverno (Claude Sautet Buzz Kulik, 1992) e $O$ piano (Jean Campion, 1993). 
Nestas ocasións, o luscofusco dura o que unha sesión de cine e ponse en tecnicolor. O que ela viu foi tamén unha escena de amor que lle pareceu interminábel. (Rivas 2011: 301)

E aló van os pasaxeiros gozando na xanela deste filme de culto chamado Galicia. (Rivas 1999: 252)

Non poderíamos rematar as nosas referencias á intertextualidade sen subliñar que as alusións ao cinema poden incluso afectar á determinación do espazo e á caracterización dos personaxes. Rivas emprega os actores ou personaxes do cinema para mostrarnos como é o aspecto físico dos personaxes definidos por el, ben por ter unha aparencia similar: "cada día que pasa se parece máis a Kim Basinguer" (2008c: 33), "o home que se parecía a Monty Clift era dende logo o seu alumno máis atento" (2006: 543); ou posuír algún trazo similar: "unha ollada Robinson", "un sorriso Mastroianni" ou "andan como Charlot". Mais tamén pode indicar unha forma de ser: "Era unha enfermeira con aspecto de vir directamente do campionato mundial de Artes Marciais. Parecíase a Silvester Stallone en Rambo aínda que tamén tiña un aire de JeanClaude Van Damne en Street Fighter" (2008e: 96). A comparación entre a enfermeira e estes actores do cine de acción non ten, esencialmente, un carácter físico senón psicolóxico-ideolóxico pois a presunta sanitaria emprega a forza, a intimidación física e psicolóxica, característica esencial dos personaxes de Stallone e Van Damne, para reter a prisioneira.

En ocasións, a forma en que os personaxes dos relatos interiorizan os protagonistas cinematográficos é igualmente definitorio. Lembremos o diálogo de Lucía Santiso e Mariscal sobre a figura de John Wayne:

E botou unha gargallada. Sabía rir de si mesmo: "O mar trae de todo. Tamén aboian as linguas. Só hai que ter bo oído. Que lle parece John Wayne?"

A moza riu. Acabaría sendo ela a entrevistada.

-É doutros tempos. O home que matou a Liberty Valance. Aí si que me gustou.

-Un home é un home-dixo el transcendente-. Iso non é doutros tempos, señorita. Iso é intemporal. $\mathrm{O}$ cine naceu coas películas do Oeste. E irase ao carallo, xa se está indo, cando remate o western. É o declive dos xéneros clásicos. Anote iso.

-Anotareino -dixo ela conciliadora-. Comentabamos que vostede era un home feito a si mesmo. (Rivas 2010b: 181)

Mariscal identifica a Wayne como un símbolo da virilidade, da forza, da violencia; Lucía, por contra, valora a xenerosidade, o desprendemento, que o leva a renunciar ao amor da súa vida e a queimar o rancho que construíra para ela en $O$ home que matou a Liberty Valan$c e$. Estas visións transcenden a interpretación dun heroe fílmico para transformarse na marca dunha determinada maneira de ver o mundo, dunha determinada maneira de $\operatorname{ser}^{32}$.

Xa con anterioridade comentabamos que a pantalla de cinema permite ao autor romper a unidade de espazo. Sucede que Rivas xoga co esa variedade de espazos e, do mesmo xeito que Buster Keaton e Woody Allen no cinema, o noso autor presenta ambos mundos interactuando, así: "Os ollos coa luz de ollos do que facía de Drácula, que aínda queimou a pantalla do cine Hércules, dous buracos deixou alí, como queimaduras de cigarro" (Rivas 2006: $720)^{33}$. A forza do actor e a súa ollada deixan unha pegada física na pantalla do cinema ${ }^{34}$.

\section{Conclusións}

O cinema, deixemos de pelexar polo inventor e recoñezamos os inventores, nace a fins do s. XIX. Este artefacto fotográfico suporía unha nova e máis precisa forma de rexistrar a realidade, por iso toda imaxe filmada, mesmo aquela que foi pensada como ficción acaba por ser documental. Paradoxalmente, toda película, incluso aquela que quere fuxir da fantasía, narra historias, peripecias, por iso, o cinema debe considerarse, en esencia, unha forma da arte de narrar.

As fronteiras entre cine e literatura, como se dunha paisaxe na néboa se tratase, son imprecisas; e, por veces, se abrazan. Comparten temas, argumentos, maioritaria pero non exclusivamente procedentes das letras -lembremos en que xa no ano 1896, un ano despois da invención do cinematógrafo, os propios

32 Unha análise máis completa pode atoparse en Castro Otero 2018a.

33 Rivas emprega esta mesma metáfora para definir ao ex-presidente do goberno español, José María Aznar (Rivas 2008b: 207).

34 Unha análise máis ampla, pode atoparse en Castro Otero 2018 b. 
irmáns Lumière adaptan Fausto ${ }^{35}$-; intercambian trazos de estilo, de tal xeito que moitas veces resulta case imposible determinar de onde procede cada un. Formas que críamos primixenias do cine tiñan a súa orixe na literatura. A narración paralela, por exemplo, foi atribuída a Griffith, mais o propio director norteamericano recoñecía a súa débeda con Dickens. Non obstante, isto non impide que moitos escritores aprenderan esta técnica na contemplación de películas e, polo tanto, a incorporen a súa caixa de ferramentas, máis dende Intolerancia que dende El ingenioso hidalgo don Quijote de la Mancha, onde, como tantas outras invencións cervantinas, pasa desapercibida.

O cine, ao tempo que se converte no espectáculo de masas por excelencia do s. XX, vai desenvolver unha linguaxe propia, vai crear uns recursos novos, como o uso de planos diferentes, os movementos de cámara, a montaxe, etc. Os nacidos a principios desta centuria foron adaptándose ás formas desta nova arte, pero os nacidos despois da década de 1930, cando o cinema era unha tecnoloxía desenvolvida e espallada -o espectáculo por excelencia-, levan incorporados xa as formas de narrar desta arte e ben merecerían ser catalogados como homo sapiens filmicus.

O cinema converteuse, insistimos, na forma de narración máis frecuente, de modo que resulta imposible pensar que as técnicas propias do audiovisual non influíran nesa xeración. Tanto foi así que os homes de letras tiveron que optar por afastarse del, buscando unha peculiaridade, un camiño propio e diferenciado, ou, pola contra, asumir as maneiras de contar do cinema para incluílas como parte do seu repertorio. A miúdo, os autores empregan unha ou outra estratexia segundo as circunstancias.

$\mathrm{Na}$ nosa opinión estas influencias poden ser de catro tipos: estruturais, visuais, auditivas e intertextuais. Dentro dos elementos estruturais, isto é organizativos, propios dos filmes podemos atopar na literatura de Rivas, cando menos, os seguintes: secuenciación, montaxe, ocularización e auriculización.

A secuencia, na literatura contemporánea, vai substituír ou cando menos convivir co capítulo como método para separar as partes da novela. Igual que a sétima arte, a literatura vai empregar formas de sutura variadas que van dende o espazo en branco semellante ao fundido en negro ata a unión sen marcas similar ao corte cinematográfico.

Os parágrafos, en ocasións, organízanse ao xeito da montaxe do cine; parecen acumulacións ordenadas ou aparentemente caóticas de planos. Este recurso en opinión de Teresa García-Abad serve, na literatura, entre outras cousas, para aproveitar mellor as transicións dende a realidade ao soño.

Quizais sexa a figura do narrador, a voz que conta a historia, o elemento estrutural máis significativo dunha obra. No cine resulta frecuente que o narrador externo ceda a ollada a un dos personaxes, mostrándonos así a súa visión. Rivas emprega con frecuencia nos seus relatos este procedemento denominado ocularización.

$\mathrm{O}$ equivalente auditivo da ocularización e a auriculización. Con este procedemento Rivas limita o poder do narrador omnisciente e consegue que o lector sinta a emoción, a angustia, o medo, do protagonista dos feitos, obrigado a escoitalos, a sentilos pasivamente dende dentro.

O ser humano ten como sentido principal o da vista, polo que non resulta sorprendente que as descricións literarias teñan a ollada como sustento principal. Con todo, a influencia do cine vai intensificar este carácter eminentemente visual que aumenta aínda máis, se cabe, coa ocularización. En ocasións, para trazar a fisionomía dos seres e dos espazos, o narrador literario parece imitar a descrición en planos (xeral, enteiro, medio, primeiro ou detalle) da sétima arte. Noutras mesmo parece desprazarse nos parágrafos como se fose unha cámara movéndose en travellings ou en panorámicas

O cinema non deixa de ser un malabarismo simbólico de luz. Os seus xogos pasan á literatura de modo que non pode estrañar que Manuel Rivas nos narre como o luar desconcerta a un violador e libera a vítima das garras da besta e nos conta como "O día traía un dispendio de luz" (2006: 35); unha luz da que un non se pode fiar porque a ameaza do golpe de estado está no ambiente por iso, en vez de clarificadora, a luz resulta excesiva, dilapidadora, un dispendio.

Tamén a tan cinematográfica presenza da imaxe dentro da imaxe ten a súa acollida dentro dos relatos rivasianos. Así, aquí e acolá, atopamos espellos e retratos -en todas as súas 
variedades- e a través deles comprendemos con maior fondura os seres que habitan os seus textos.

Dentro das influencias auditivas, ademais do inmenso caudal léxico e de paremias que aporta, cómpre destacar o carácter coloquial dos diálogos que semellan os do cine (e do teatro) e suxiren, como ben expresaba Luis Goytisolo, o plano contra plano. Igualmente a música que aparece como unha auténtica banda sonora. O barco pirata de Bala Perdida, aparece como unha "súbita claridade de verbena" pois libera os barcos pesqueiros da ameaza terrible do Zaratrusta.

$\mathrm{O}$ cine tenos acostumados a emocionarnos a través do ruído. Un son agudo no silencio absoluto pode transmitir unha ameaza, o son dun bolígrafo contra a ventá a desilusión do desamor. Tamén nos seus textos o autor de Monte Alto emprega os ruídos para situarnos, case epidermicamente, nos abismos emocionais. Así, por exemplo, o son dos ratos no faiado expresa a ansiedade e a síndrome de abstinencia do mozo protagonista en Os comedores de patacas.

$\mathrm{Na}$ obra de Rivas existe unha diversidade enorme de referencias ao cinema: as películas, os directores, os personaxes os actores, os oficios máis humildes como o perteguista, o extra ou a maquilladora e tamén a tecnoloxía e a técnica desta arte aparecen por todas partes para expresar as opinións do autor, a súa visión da vida, do mundo, da sociedade... e tamén constitúen un recurso para a descrición dos personaxes, sexa pola similitude física, psicolóxica ou ideolóxica cos protagonistas do cinema..

A emoción cinéfila de Rivas -no sentido etimolóxico da palabra - chega ao punto de empregar a sétima arte para expresar a beleza do mundo cando esta se manifesta na súa plenitude: "E aló van os pasaxeiros gozando na xanela deste filme de culto chamado Galicia" (Rivas 1999: 252).

Nalgún momento da súa infancia, Manuel Rivas entrou na caverna do cine Hércules ${ }^{36}$ e logo na do Monelos ou na do Portazgo, os máis próximos ao seu fogar ${ }^{37}$ e visitando estas e outras covas acabou por completar a súa formación como homo filmicus; mais un homo filmicus capaz de emocionarse con todas as formas de sentir a cultura.

Este é o tempo en que a terra se encolle baixo o chal da xeada. As néboas e as brétemas esvaen o acabado das cousas. O sol que reina é un vello Lear con ganas de ir cedo ao leito. Engúrrase en grelo e doce nabiza. E os defuntos, os defuntiños, os do club da Santa Compaña, os do círculo social da Estadea, os emigrantes galegos de Extramundi, as nosas pantasmas, andan por aí cos pés fríos, asomando polas chemineas das lareiras, na procura de alguén que dea conversa nestas noites noitaregas.

A maioría da xente está a ver a televisión e non lle fai nin caso á ánima.

-Ei, Manuel! Hai aquí un na porta que di que é a Santa Compaña e a ver se lle damos un pouco de parola.

-Ai, Carmiña! Dille que hoxe non podo que estou a facer zapping. Se quere que pase pero que estea caladiño.

Non é de estrañar que unha das cousas que máis odia o fantasma galego sexa a televisión. Vén o defunto dar unha volta pola casa natal para explicar as novidades da súa viaxe ao Alén, todo cheo de estreliñas, e que pensan que é o que atopa? Pois a todos os vivos vendo unha película de Drácula na TVG. Se cadra, por solidariedade, aínda mira un pouquiño, máis logo cansa e vaise.

-E xa marchou a Santa Compaña? -di o home.

-E como non ía liscar? O caso que lle fixeches!

-É que sempre veñen no mellor da película. Xusto cando nomean a Drácula presidente de Transilvania.

-Non sei se non sería da familia, que o can nin lle ladrou. Marchar, marchou fungando, rosmando que xa non había educación nin farrapo de gaita.

Por iso, cando unha ánima en pena asoma por unha fiestra e encontra un galego de seu mirando a lendaria película do lume do ameneiro na lareira, sente de novo latexos no reloxo parado do corazón e peta cos cotenos unha pandeirada no vidro. O galego O'Fetén ábreselle a porta, mándao pasar e ofrécelle, claro, algo de cea. (Rivas 2004: 52)

\footnotetext{
36 “As primeiras películas vímolas no cine Hércules, no Monte Alto. Todos en vilo na cámara escura. O cinema enteiro imitaba como unha liberación o ruxido do león da Metro" (Rivas 2012: 151).

37 "Trae os carteis dos cinemas. Os nosos, os máis próximos, son o cine Portazgo, na rúa do Burgo e o cine Monelos, na porta da cidade" (Rivas 2012: 105).
} 
Rivas mergúllase na tradición cultural na que vive, acepta os seus mitos, neste caso, a Santa Compaña. Asúmeos dende a sensibilidade e dende o humor, non dende o inmobilismo. Os espíritos que dominaban as corredoiras das aldeas van hoxe de casa en casa na procura de alguén que os reciba e perciben a indiferenza dunha xeración que prefire xa os mitos alleos (Drácula), transformados estes en película (desta volta observada na televisión). Parecería como se o autor renegase do homo filmicus e o criticase pola súa falta de empatía; mais no momento de maior emoción, cando por fin a ánima en pena atopa un fogar receptivo, cando conecta coa beleza do pasado non pode senón expresalo en termos cinematográficos e por iso o galego O'Fetén, amante das tradicións, está a mirar a "lendaria película do lume do ameneiro".

Quizás este fragmento sexa un resumo perfecto de toda a obra de Rivas, nel aparece o espírito crítico con quen non ten sensibilidade para a conservación da cultura propia, o tratamento entrañable de todos os personaxes, o humor, o lirismo e todo decorado por unha pátina de cine.

\section{Referencias bibliográficas}

Alberti, Rafael (1994): Antología poética. Madrid: Alianza Editorial.

Àngelova Nènkova, Vèselka e Carlos González-Espresati (2008): "Alternancia e fixación do diminutivo nas unidades fraseolóxicas”, Cadernos de Fraseoloxía Galega 10, pp. 15-33.

Antón, Patricia (2007): La obra novelística de Torrente Ballester y el cine: Los gozos y las sombras. Análisis comparativo-textual. Tese de doutoramento inédita. A Coruña: Universidade.

Austen, Jane (2015): Sentido y sensibilidad. Barcelona: Penguin Clásicos.

Beaugrande, Robert-Alain de e Wofgang Ulrich Dressler (1997): Introducción a la lingüística del texto. Barcelona: Ariel.

Becerra Suárez, Carmen (2003): "Notas sobre la descripción en cine y en literatura", en J. A. Pérez Bowie (ed.), La adaptación cinematográfica de textos literarios. Teoría y práctica. Salamanca: Plaza Universitaria Ediciones, pp. 49-56.

Benet, Vicente J. (2007): La cultura del cine. Introducción a la historia y estética del cine. Barcelona: Paidós.

Castro Otero, Salvador (2018a): "La caracterización de los personajes a través de las imágenes de cine en la obra de Manuel Rivas", en Tropelías. Revista de Teoría de la Literaruta y Literatura Comparada 30, pp. 211-224.

_ (2018b): “As salas de cine na obra de Manuel Rivas", Revista de Lenguas y Litetaturas catalana, gallega y vasca 23 , pp. 99-111

Chatman, Seymour (1990): Historia y discurso. La estructura narrativa en la novela y el cine. Madrid: Taurus.

Dostoievski, Fiódor (2013): Crimen y castigo. Madrid: Cátedra.

García-Abad García, Teresa (2005): Intermedios. Estudios sobre literatura, teatro y cine. Madrid: Fundamentos.

Gimferrer, Pere (1999): Cine y literatura. Barcelona: Seix-Barral.

Gómez López, Encarnación (2010): "De la literatura al cine: aproximación a una teoría de la adaptación”, en VV.AA., Cuadernos de filología alemana. Anejo II. Madrid: Universidad Complutense, pp. 245-255.

Goytisolo, Luis (1995): "El impacto de la imagen en la narrativa española contemporánea", Academia. Revista del cine español 12, pp. 11-30.

Jost, François (2002): El ojo cámara. Entre film y novela. Buenos Aires: Catálogos S.R.L.

López Piñeiro, Carlos Aurelio (2018): As catro estacións do relato audiovisual. Técnica do relato fílmico. Pontevedra: Fundación SGAE.

Morant, Ricard e Debra Westall (2005): "Lo que el cine nos dejó: la herencia fraseológica", en J. de D. Luque Durán e A. Pamies Bertrán (eds.), La creatividad en el lenguaje: colocaciones idiomáticas y fraseológicas. Granada: Granada Lingvistica.

Nykvist, Sven (2002): Culto a la luz. Madrid: Ediciones del Imán.

Rivas, Manuel (1997): El periodismo es un cuento. Madrid, Alfaguara.

(1999): Galicia, Galicia. Vigo: Xerais

(2002): Muller no baño. Vigo: Xerais.

(2003): Do descoñecido ao descoñecido. Obra poética (1980-2003). A Coruña: Espiral Maior. 
(2004): Unha espía no reino de Galicia. Vigo: Xerais

(2005a): O lapis do carpinteiro. Vigo: Xerais.

(2005b): O heroe. Vigo: Xerais.

(2006): Os libros arden mal. Vigo: Xerais.

(2008a): En salvaxe compaña. Vigo: Xerais.

(2008b): A corpo aberto. Vigo: Xerais.

(2008c): Os comedores de patacas. Vigo: Xerais.

(2008d): Os Grouchos. Vigo: Xerais.

(2008e): Bala perdida. Vigo: Xerais.

(2009a): Episodios galegos. Tempos de esperpento. Vigo: Xerais.

(2010a): Todo ben. Vigo: Xerais.

(2010b): Todo é silencio. Vigo: Xerais.

(2011): O máis estraños. Contos reunidos. Vigo: Xerais.

(2012): As voces baixas. Vigo: Xerais.

(2013): Vicente Ferrer. Rumbo a las estrellas, con dificultades. Barcelona: RBA.

Taléns, Jenaro (2002): "Un matrimonio de interés: cine y literatura", Versants. Revue suisse des littératures romanes 42 , pp. 5-15.

Tarrío, Anxo (coord) (1998): Dicionario de termos literarios. Santiago de Compostela: Centro Ramón Piñeiro para a Investigación en Humanidades, Xunta de Galicia.

Trueba, Fernando (2006): Mi diccionario de cine. Barcelona: Círculo de lectores.

Valle-Inclán, Ramón María del (1980): Luces de bohemia. Madrid: Espasa Calpe.

Vazquez Varela, José Manuel e Antonio Rodríguez Colmenero (1993): Galicia Arte. Arte prehistórica e romana. A Coruña: Hércules Ediciones.

Vilavedra, Dolores (2011b): "Guerra Civil y literatura gallega", Revista internacional de estudios vascos 8, pp. 62-67. 